\title{
Short-Range-Order Minerals and Dominant Accessory Properties Controlling P Sorption in Tropical Tephra Soils of the Cameroon Volcanic Line
}

\author{
Roger Kogge Enang1*, Bernard Palmer Kfuban Yerima', Georges Kogge Kome', \\ Eric van Ranst ${ }^{2}$ \\ ${ }^{1}$ Soil Science Department, Faculty of Agronomy and Agricultural Sciences, University of Dschang, Dschang, Cameroon \\ ${ }^{2}$ Geology Department, Faculty of Sciences, Ghent University, Ghent, Belgium \\ Email: *enangrog@yahoo.com
}

How to cite this paper: Enang, R.K., Yerima, B.P.K., Kome, G.K. and van Ranst, E. (2019) Short-Range-Order Minerals and Dominant Accessory Properties Controlling P Sorption in Tropical Tephra Soils of the Cameroon Volcanic Line. Open Journal of Soil Science, 9, 113-139.

https://doi.org/10.4236/ojss.2019.98008

Received: July 28, 2019

Accepted: August 27, 2019

Published: August 30, 2019

Copyright (c) 2019 by author(s) and Scientific Research Publishing Inc. This work is licensed under the Creative Commons Attribution International License (CC BY 4.0).

http://creativecommons.org/licenses/by/4.0/

\section{(c) (i) Open Access}

\begin{abstract}
Knowledge on soil properties likely to influence P sorption in tephra soils is very important for sustainable management of available P. Sorption studies on six tephra soils were conducted to relate $\mathrm{P}$ sorption to soil characteristics in order to identify those with potential influence on $\mathrm{P}$ sorption. Four equilibrium-based sorption models commonly encountered in soil studies (Langmuir, Freundlich, Temkin, and Van Huay) were used to describe P sorption in the soils. $\mathrm{P}$ sorption was determined by measuring the residual $\mathrm{P}$ content of a clarified equilibrating solution of $0.02 \mathrm{~N} \mathrm{KCl}$ containing varying concentrations $(0,5,10,15,30,40,50,60,80$, and $100 \mathrm{mg} / \mathrm{L})$ of $\mathrm{P}_{\text {as }} \mathrm{KH}_{2} \mathrm{PO}_{4}$ after mixing with $1 \mathrm{~g}$ of soil in duplicates for 16 hours at $25^{\circ} \mathrm{C}$. Maximum amount of $\mathrm{P}$ sorbed for the varying $\mathrm{P}$ concentrations used ranged from 2080 to 5402 $\mathrm{mg} / \mathrm{kg}$ with a potential for greater $\mathrm{P}$ sorption maxima at higher $\mathrm{P}$ solution concentrations. P sorption in these soils was best described by the Langmuir and Freundlich models. Allophane and ferrihydrite are the principal species controlling the high $\mathrm{P}$ sorption in these soils. $\mathrm{pH}-\mathrm{NaF}$ proved to be a potentially reliable test for assessing the presence of allophanic materials and thus for estimating $\mathrm{P}$ sorbed. This work would guide both effective and efficient $\mathrm{P}$ fertilizer management with economic implications for both the study area and similar environments.
\end{abstract}

\section{Keywords}

Allophane, Ferrihydrite, Mount Kupe, Mount Manengouba, Sorption Isotherms 


\section{Introduction}

Adsorption is the accumulation of a substance at an interface between the solid surface and the bathing solution [1]. It is one of the most important processes in soils that affect transport of nutrients and contaminants as it determines the quantity of crop nutrients, metals, pesticides, and other organic chemicals retained on soil surfaces [1]. Phosphorous is a major element which plays a fundamental role in agronomy and biogeochemical cycles, but is unfortunately not very abundant in soils [2]. Phosphorous is capable of forming innumerable covalent organo-phosphorous compounds and to bind to $\mathrm{C}, \mathrm{N}, \mathrm{O}, \mathrm{Al}, \mathrm{Fe}$, and $\mathrm{Ca}$.

In tephra soils characterized by high organic matter contents and allophanic minerals, this element can become very unavailable as it is easily adsorbed by the latter. Tephra soils, or better still soils with andic soil properties are usually classified as variable charge soils with unique properties that make them respond in a particular manner to different management [3]. These soils are known to have a high P-retention capacity thereby posing a problem of $\mathrm{P}$ deficiency for crop production; thus requiring heavy applications of $P$ fertilizers [4]. However, despite the acidic nature of some volcanic soils, such as the Bokwango Andosols on the slopes of Mt. Fako in Cameroon, with $\mathrm{pH}-\mathrm{H}_{2} \mathrm{O}$ ranging between 4.9 and 5.5, at which high concentrations of exchangeable aluminium $(0.1-0.3 \mathrm{meq} / 100 \mathrm{~g}$ soil) were observed [5] and susceptible to fix phosphorus, crops like cocoyams (Colocascia esculenta) and plantains (Musa spp.) still perform well with very good yields. The mechanism which enables these soils to continue to produce very well despite their acidic nature and hence the high $\mathrm{P}$ sorption of such soils has been puzzling, requiring in-depth studies. $\mathrm{P}$ sorption is known to be mostly associated with $\mathrm{Fe}$ and $\mathrm{Al}$ oxides, extractable $\mathrm{Ca}$ and $\mathrm{Mg}, \mathrm{pH}$, soil texture, and carbon content [6]. This phosphorus adsorption depends on many factors such as concentration, crystallinity, specific surface area, and the configuration and concentration of hydroxyl groups on the surface of iron oxides, which in turn are affected by the formation route, parent material, degree of weathering, soil solution composition, drainage conditions and $\mathrm{pH}$ [7]. In $\mathrm{P}$ sorption experimental studies, an adsorptive solution of a known composition and volume is equilibrated with a known amount of adsorbent at a constant temperature and pressure for a period of time such that equilibrium (adsorption reaches a steady state or no longer changes after a period of time) is attained [1]. This can be achieved following a variety of methods. One common and easiest method usually employed in studying P sorption in soils is the batch method [8]. In this method, the solid or adsorbent (soil) is shaken in the solution or adsorbate (e.g., $\mathrm{KH}_{2} \mathrm{PO}_{4}$ solution) until the adsorption equilibrium is reached, after which the remaining solute concentration is measured. However, this method has numerous disadvantages. For example, the solid/solution ratio is often too high or too low compared to the natural conditions in soils [8]. This is one among many factors that render $\mathrm{P}$ sorption studies very challenging and so most often limited to qualitative rather than quantitative appreciation. 
In this study, P sorption was conducted on six representative tephra soils (five Andosols and one aluandic Cambisol) using four sorption models commonly applied in soil P sorption studies [9] [10] [11] [12] with the aim of comparing these models and identifying soil characteristics likely to influence proper $\mathrm{P}$ sorption assessment. The effectiveness of these models in describing P sorption as observed in prior investigations [1] dictated their choice.

\section{Materials and Methods}

\subsection{Description of Study Area (Geological and Environmental Setting)}

The study area covers two massifs in the south-west region of Cameroon; Mts. Kupe and Manengouba (Figure 1).

Morphologically and geologically, the Kupe massif consists of two very different parts: a syenitic horst on the one hand, and a basaltic cover on the other [13], which are the sites of many recent monogenic volcanoes [14]. The lavas

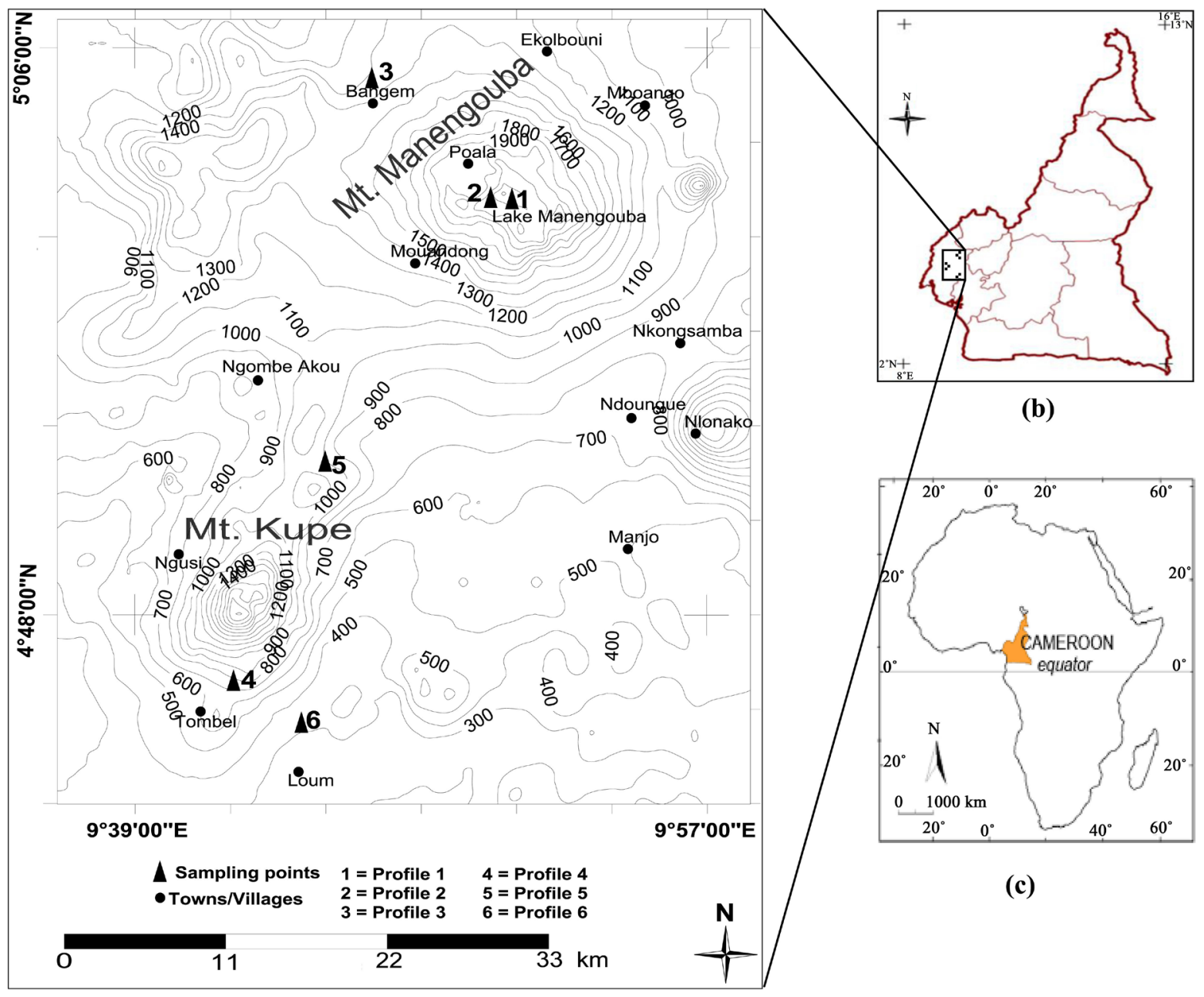

(a)

Figure 1. (a) Topographic map of study area showing sampling sites; (b) Cameroon map showing study area; (c) Africa map showing location of Cameroon. 
that cover the area and especially the ashes spread over the greater part of the mountain are believed to have resulted from these craters [13].

On the slopes and foot of Mt. Kupe lie many small cones of ash and lapilli, ranging between 50 and $150 \mathrm{~m}$ in height. The proportion of pyroclastic products (blocks, bombs, lapilli and ashes, with many syenite and gneiss enclaves) is much higher than that of the lavas. These pyroclastics are of Quaternary origin [14].

Previous studies by [15] showed that most of the soils, especially those located on the western slopes of Mt. Kupe, are of two Reference Soil Groups; Andosols and Cambisols with dominant parent materials being pyroclastics (mainly block and lapilli tephra).

The soils are generally stratified and present erratic variations in most of the physico-chemical properties. Mean annual rainfall around Mt. Kupe stands at $3096 \mathrm{~mm}$, while mean annual temperature and relative humidity stand at $25^{\circ} \mathrm{C}$ and $86 \%$, respectively.

The Manengouba massif is of volcanic origin and harbours Mt. Manengouba (2396m). Its volcanic story is related to four chronological stages: 1) forming of the early Manengouba shield volcano between 1.55 and $0.94 \mathrm{Ma}$; 2) building of the Eboga strato-cone between 0.94 and $0.89 \mathrm{Ma}$; 3) caldera collapse and silicic extrusions of the Elengoum Complex between 0.89 and $0.70 \mathrm{Ma}$; and 4) intra-caldera and flank activity between 0.45 and $0.11 \mathrm{Ma}$ [16]. The volcanic rocks are attributed to two magmatic events. The first and main magma emitted produced the shield volcano, the strato-cone, and the syn- to post-caldera extrusions, displaying a complete series from basanites to trachytes (magmatic Group 1). The second magma emitted, is limited to the late and flank activity and evolved from basanites to trachy- phonolite materials. Both magmatic groups belong to the under-saturated alkaline sodic series [16].

The climate on Mt. Manengouba and environs is equatorial, with heavy rainfall fairly well distributed throughout the year. Mean annual rainfall is $2316 \mathrm{~mm}$, while mean annual temperature and relative humidity are $20.3^{\circ} \mathrm{C}$ and $84 \%$, respectively.

Six sites, representative of the study area were selected for the study. On Mt. Manengouba, dominated by grassland vegetation, two sites were selected on old (P1) and more recent (P2) volcanic ejecta. At the foot of Mt. Manengouba, dominated by forest vegetation on the old basement, a third profile was identified (P3). This site is situated on a more stable geomorphic surface subject to higher water infiltration and thus more intense weathering. It constitutes an older tephra flow parent material which has not been influenced by the recent flows of sites 1 and 2.

On Mt. Kupe, dominated by forest vegetation, three profiles were selected following a toposequence at altitudes of 1030 (P5) m, $583 \mathrm{~m}$ (P4) and $465 \mathrm{~m}$ (P6). The characteristics of the sites are summarized in Table 1 . The soil profiles were described following the FAO recommendations [17]. Soil samples were collected per horizon and stored in polythene bags. Samples for bulk density were collected in duplicates to evaluate the consistency of analytical results in order to minimize measurement errors. 
Table 1. Summary of site characteristics harboring the six soil profiles.

\begin{tabular}{|c|c|c|c|c|c|c|}
\hline $\begin{array}{l}\text { Profile number } \\
\text { (site) }\end{array}$ & Location & Land use/Vegetation & Physiography & $\begin{array}{l}\text { Relief/ } \\
\text { Elevation } \\
(\mathrm{m})\end{array}$ & $\begin{array}{l}\text { Parent } \\
\text { material }\end{array}$ & $\begin{array}{l}\text { Classification } \\
\text { (IUSS Working } \\
\text { Group WRB, } \\
\text { 2015) }\end{array}$ \\
\hline $\begin{array}{l}\text { Profile } 1 \\
\text { Lake Manengouba } \\
\text { series. }\end{array}$ & $\begin{array}{l}\text { Lat. } \\
5^{\circ} 02^{\prime} 14.6^{\prime \prime} \mathrm{N} \text {, } \\
\text { Long. } \\
9^{\circ} 49^{\prime} 34.4^{\prime \prime} \mathrm{E}\end{array}$ & $\begin{array}{l}\text { Herbaceous (short grassland } \\
\text { vegetation) with patches of shrubs. } \\
\text { Dominant grass species is the } \\
\text { "cow grass". }\end{array}$ & $\begin{array}{l}25 \%-30 \% \text { (Moderately steep). } \\
\text { General gradient into the lake is } \\
\text { very steep ( } 60 \%-70 \%) \text { marked } \\
\text { by intermediate V-shaped } \\
\text { valleys. Good internal and } \\
\text { external drainage. Signs of } \\
\text { geologic erosion (slight). }\end{array}$ & $\begin{array}{l}\text { Highland } \\
1964\end{array}$ & $\begin{array}{l}\text { Block } \\
\text { tephra }\end{array}$ & $\begin{array}{l}\text { Eutric silandic } \\
\text { Andosol (colluvic, } \\
\text { loamic) }\end{array}$ \\
\hline $\begin{array}{l}\text { Profile } 2 \\
\text { Top of the rim of } \\
\text { the first caldera } \\
\text { (external caldera) } \\
\text { on Mount } \\
\text { Manengouba. }\end{array}$ & $\begin{array}{l}\text { Lat. } \\
5^{\circ} 02^{\prime} 44.1^{\prime \prime} \mathrm{N}, \\
\text { Long. } \\
9^{\circ} 48^{\prime} 53.4^{\prime \prime} \mathrm{E}\end{array}$ & $\begin{array}{l}\text { Herbaceous and shrubs. Grassland } \\
\text { vegetation with "cow grass" as } \\
\text { dominant species. Touristic site, } \\
\text { sightseeing, grazing land for cattle. }\end{array}$ & $\begin{array}{l}\text { Highland, undulating landscape } \\
\text { with varying slopes from } 0 \% \text { - } \\
1 \% \text { (flat to nearly level) to about } \\
70 \% \text { (very steep) slopes. Rim of } \\
\text { caldera composed of intermittent } \\
\text { hills and valleys, and micro-relief } \\
\text { of beds about } 2 \times 2 \mathrm{~m} \text { in size. }\end{array}$ & $\begin{array}{l}\text { Highland } \\
1935\end{array}$ & $\begin{array}{l}\text { Lapilli } \\
\text { tephra }\end{array}$ & $\begin{array}{l}\text { Eutric skeletic } \\
\text { silandic Andosol } \\
\text { (fragic, } \\
\text { hyperhumic, } \\
\text { loamic) }\end{array}$ \\
\hline $\begin{array}{l}\text { Profile } 3 \\
\text { Bangem series, } \\
\text { cultivated } \\
\text { farmland }\end{array}$ & $\begin{array}{l}\text { Lat. } \\
5^{\circ} 05^{\prime} 27.7^{\prime \prime} \mathrm{N}, \\
\text { Long. } \\
9^{\circ} 45^{\prime} 58.5^{\prime \prime} \mathrm{E}\end{array}$ & $\begin{array}{l}\text { Farmland used for cultivation of } \\
\text { coffee (Coffea spp.), plantain and } \\
\text { banana (Musa spp.), plum } \\
\text { (Dacryodes edulis), African oil } \\
\text { palm (Elaeis guineensis), taro } \\
\text { (Colocascia esculenta) and cassava } \\
\text { (Manihot esculenta). }\end{array}$ & $\begin{array}{l}\text { Mountainous and undulating } \\
\text { landscape, } 10 \%-15 \% \text { slope } \\
\text { (Strongly sloping). }\end{array}$ & $\begin{array}{l}\text { Highland } \\
1155\end{array}$ & $\begin{array}{l}\text { Block } \\
\text { tephra }\end{array}$ & $\begin{array}{l}\text { Dystric aluandic } \\
\text { Cambisol (humic, } \\
\text { loamic, tephric) }\end{array}$ \\
\hline $\begin{array}{l}\text { Profile } 4 \\
\text { Kupe series (at } \\
\text { foot of mount } \\
\text { Kupe) }\end{array}$ & $\begin{array}{l}\text { Lat. } \\
4^{\circ} 45^{\prime} 05.4^{\prime \prime} \mathrm{N}, \\
\text { Long. } \\
9^{\circ} 41^{\prime} 32.1^{\prime \prime} \mathrm{E}\end{array}$ & $\begin{array}{l}\text { Cultivated farmland: Cocoa } \\
\text { (Theobroma cacao) farm with } \\
\text { presence of the African oil palm } \\
\text { (Elaeis guineensis), cocoyam } \\
\text { (Colocasia esculenta), plum } \\
\text { (Dacryodes edulis), variety of } \\
\text { herbs, and some forest tree } \\
\text { species. }\end{array}$ & $\begin{array}{l}\text { Mountainous and undulating } \\
\text { landscape. } 10 \%-15 \% \text { slope } \\
\text { (Strongly sloping). Good } \\
\text { drainage, no signs of erosion. }\end{array}$ & $\begin{array}{l}\text { Graben } \\
583\end{array}$ & $\begin{array}{l}\text { Block and } \\
\text { lapilli } \\
\text { tephra }\end{array}$ & $\begin{array}{l}\text { Eutric skeletic } \\
\text { silandic Andosol } \\
\text { (fragic, loamic) }\end{array}$ \\
\hline $\begin{array}{l}\text { Profile } 5 \\
\text { Essossong series, } \\
\text { virgin forest }\end{array}$ & $\begin{array}{l}\text { Lat. } \\
4^{\circ} 51^{\prime} 25.0^{\prime \prime} \mathrm{N}, \\
\text { Long. } \\
9^{\circ} 43^{\prime} 32.3^{\prime \prime} \mathrm{E}\end{array}$ & $\begin{array}{l}\text { Montane forest with a variety of } \\
\text { forest trees, marantaceae, herbs, } \\
\text { etc. }\end{array}$ & $\begin{array}{l}\text { Mountainous and undulating } \\
\text { landscape. Good drainage. No } \\
\text { signs of erosion. } 10 \%-15 \% \text { slope } \\
\text { (strongly sloping). }\end{array}$ & $\begin{array}{l}\text { Highland } \\
1030\end{array}$ & $\begin{array}{l}\text { Block and } \\
\text { lapilli } \\
\text { tephra }\end{array}$ & $\begin{array}{l}\text { Eutric } \\
\text { Akroskeletic } \\
\text { silandic Andosol } \\
\text { (colluvic, } \\
\text { hyperhumic, } \\
\text { loamic) }\end{array}$ \\
\hline $\begin{array}{l}\text { Profile } 6 \\
\text { Loum forest } \\
\text { reserve }\end{array}$ & $\begin{array}{l}\text { Lat. } \\
4^{\circ} 43^{\prime} 53.2^{\prime \prime} \mathrm{N} \text {, } \\
\text { Long. } \\
9^{\circ} 42^{\prime} 06.2^{\prime \prime} \mathrm{E}\end{array}$ & $\begin{array}{l}\text { Protected forest. Variety of forest } \\
\text { trees. Protected forest under } \\
\text { exploitation for farming. }\end{array}$ & $\begin{array}{l}\text { Undulating lowland with patches } \\
\text { of rock outcrops, } 15 \%-20 \% \\
\text { slope (moderately steep). }\end{array}$ & $\begin{array}{l}\text { Graben } \\
465\end{array}$ & $\begin{array}{l}\text { Block and } \\
\text { lapilli } \\
\text { tephra }\end{array}$ & $\begin{array}{l}\text { Eutric silandic } \\
\text { Andosol (colluvic, } \\
\text { loamic). }\end{array}$ \\
\hline
\end{tabular}

\subsection{Laboratory Methods}

Soil samples were air-dried, crushed and sieved on a $2 \mathrm{~mm}$ sieve. The $<2 \mathrm{~mm}$ fractions were used for the analyses.

Soil physico-chemical analyses were conducted following standard methods. Soil organic carbon (OC) content was determined following the Walkley and Black method with prior determination of a recovery factor, while OM was obtained from the equation $\mathrm{OM}=\mathrm{OC} \times 1.724$ (based on the recovery factor) [18]. 
Bulk density (BD) was determined in duplicates as the oven dry $\left(105^{\circ} \mathrm{C}\right)$ mass of each undisturbed core sample per unit volume [19]. A 1:2.5 soil- $\mathrm{H}_{2} \mathrm{O}$ and 1:2.5 soil- $\mathrm{KCl}$ solutions were used for $\mathrm{pH}-\mathrm{H}_{2} \mathrm{O}$ and $\mathrm{pH}-\mathrm{KCl}$ determinations, respectively. pH-NaF was determined after agitating $1 \mathrm{~g}$ of soil in $50 \mathrm{ml}$ of $1 \mathrm{~N} \mathrm{NaF}$ for two minutes. Texture was determined by the pipette method [19]. Acid ammonium oxalate extractable $\left(\mathrm{Al}_{\mathrm{o}}, \mathrm{Fe}_{\mathrm{o}}, \mathrm{Si}_{\mathrm{o}}\right.$ and $\left.\mathrm{Mn}_{\mathrm{o}}\right)$, dithionite citrate bicarbonate (DCB) extractable $\left(\mathrm{Al}_{\mathrm{d}}, \mathrm{Fe}_{\mathrm{d}}, \mathrm{Si}_{\mathrm{d}}\right.$, and $\left.\mathrm{Mn}_{\mathrm{d}}\right)$, and pyrophosphate extractable $\left(\mathrm{Al}_{\mathrm{p}}\right)$ were determined by inductively coupled plasma-optical emission spectroscopy (ICP-OES).

Calculation of the allophane content was done according to the method of [20] as follows:

$$
\text { \%allophane }=\% \operatorname{Si} \times(100 / y)
$$

where $y$ is the $\% \mathrm{Si}$ in allophane, calculated using the equation $y=23.4-5.1 x$, where $\mathrm{x}=\left(\mathrm{Al}_{\mathrm{o}}-\mathrm{Al}_{\mathrm{p}}\right) / \mathrm{Si}_{\mathrm{o}}$ atomic ratio.

Calculation of the ferrihydrite content was done using the equation of [21] as follows:

$$
\% \text { ferrihydrite }=1.7 \times \mathrm{Fe}_{\mathrm{o}}
$$

The subscripts ${ }_{o}$ and ${ }_{p}$ in the equations above represent oxalate and pyrophosphate extractions, respectively.

Phosphorus sorption was conducted following the procedures according to [22]. The P sorption was determined by measuring the residual $\mathrm{P}$ content of a clarified equilibrating solution of $0.02 \mathrm{~N} \mathrm{KCl}$ (to maintain the ionic strength) containing varying concentrations $(0,5,10,15,30,40,50,60,80$, and $100 \mathrm{mg} / \mathrm{L})$ of $\mathrm{P}$ as $\mathrm{KH}_{2} \mathrm{PO}_{4}$ after mixing with $1 \mathrm{~g}$ of soil in duplicates for 16 hours at $25^{\circ} \mathrm{C}$. The solution was decanted into centrifuge tubes and centrifuged at $4000 \mathrm{rpm}$ for 30 minutes using an HRT $20 \mathrm{MM}$ model Multifunctional Intelligent Centrifuge. The remaining $\mathrm{P}$ in the solution after equilibration was determined colorimetrically based on the reaction with ammonium molybdate. In the procedure, $1 \mathrm{ml}$ aliquote of the centrifuged solution was pipetted into a test tube and $10 \mathrm{ml}$ of a mixture of ammonium molybdate, sulphuric acid, potassium antimonyl tartrate, and ascorbic acid added with subsequent development of the molybdenum blue colour [22]. The absorbance, which is directly proportional to the remaining $\mathrm{P}$ content in solution, was measured at $882 \mathrm{~nm}$ using a Searchtech $722 \mathrm{~N}$ model visible spectrophotometer. The amount of $\mathrm{P}$ sorbed was then calculated as the difference between the initial concentration in the equilibrating solution and the remaining $\mathrm{P}$ using (1).

$$
\text { P sorbed }(\mathrm{mg} / \mathrm{kg})=\frac{\left(C_{i}-C_{f}\right) \times V}{w}
$$

where $C_{i}$ is the initial $\mathrm{P}$ concentration in the equilibrating solution, $C_{f}$ is the $\mathrm{P}$ concentration after adsorption, $V$ is the volume of equilibrating solution used, and $w$ is the oven-dry $\left(105^{\circ} \mathrm{C}\right)$ equivalent mass of the soil sample. 


\subsection{P Sorption Description}

To describe $\mathrm{P}$ sorption in the six soils, four equilibrium-based models commonly used for soils were used viz: Langmuir, Freundlich, Temkin, and Van Huay.

The linear form of the simple Langmuir equation [9] is defined by (2) as follows:

$$
\frac{C}{q}=\frac{1}{k b}+\frac{C}{b}
$$

where $q$ is the amount of adsorption (adsorbate per unit mass of adsorbent) in $\mathrm{g} \cdot \mathrm{kg}^{-1}, C$ is the equilibrium or final adsorptive concentration, $k$ is a constant related to the binding strength, and $b$ is the maximum amount of adsorptive that can be adsorbed (monolayer coverage). The Langmuir equation is based on some assumptions which are not valid for the heterogeneous surfaces found in soils [1]. Plotting $C / q$ vs. $C$ produces the slope equal to $1 / b$ and the intercept equal to $1 / k b$.

The Freundlich equation [10] is defined as follows (3):

$$
q=K_{d} C^{1 / n}
$$

where $q$ is the amount of adsorption (adsorbate per unit mass of adsorbent) in $\mathrm{g} \cdot \mathrm{kg}^{-1}, C$ is the equilibrium or final adsorptive concentration, $K_{d}$ is the distribution coefficient, and $n$ is a correction factor. The linear form of the Freundlich Equation (4) is as follows:

$$
\log q=\frac{1}{n} \log C+\log K_{d}
$$

The slope is the value of $1 / n$ and the intercept is equal to $\log K_{d \cdot}$.

One of the major disadvantages of the Freundlich equation is that it does not predict an adsorption maximum. The single $K_{d}$ term in the Freundlich equation implies that the energy of adsorption on a homogeneous surface is independent of surface coverage.

The Temkin adsorption isotherm [11] is defined by (5) as follows:

$$
X=a+b \ln C
$$

where $b$ is the buffer capacity $(\mathrm{mL} / \mathrm{g}), X$ is the amount of $\mathrm{P}$ adsorbed $(\mathrm{mg} / \mathrm{kg}), C$ is the equilibrium solution concentration $(\mathrm{mg} / \mathrm{L})$. A plot of $X$ against $\ln C$ gives a slope equal to $b$ and an intercept equal to $a$.

The Van Huay isotherm [12] is defined as follows (6):

$$
\frac{x}{m}=m+n \sqrt{C}
$$

where $x$ is the amount of phosphate adsorbed $(\mathrm{mg} / \mathrm{kg}), C$ is the concentration of fluid phase $(\mathrm{mg} / \mathrm{L}), n$ is the Van Huay adsorption coefficient $(\mathrm{L} / \mathrm{kg})$, and $m$ is the Van Huay constant parameter. A plot of $x$ against $C^{1 / 2}$ gives a gradient equal to $m n$ and an intercept equal to $\mathrm{m}^{2}$.

\subsection{Statistical Analysis}

The Pearson's correlation test was conducted to assess the association between $\mathrm{P}$ 
sorbed, soil properties and sorption parameters of the various equilibrium-based models, while multiple linear regression analysis was conducted on soil properties to explain possible relationships between them. All statistical analyses were facilitated using Microcal Origin Version 6.0 [23], Microsoft Excel 2007 [24] and SPSS for Windows Version 17.0 [25].

\section{Results and Discussion}

\subsection{Physico-Chemical Properties}

From the physico-chemical properties (Table 2), profiles 1, 2, 4, 5 and 6 have texture classes [17] ranging between loam, silty loam, loamy sand, and sandy loam. Profile 3 alone has a clay loam texture in some of its horizons with higher clay contents compared to the others indicative of a more advanced stage of development. The soils are slightly acidic to basic, except for profile 3 which has $\mathrm{pH}-\mathrm{H}_{2} \mathrm{O}$ values less than 5.5. Organic carbon contents are generally high in the surface horizons and decrease with depth. Bulk density is generally low (less than $0.9 \mathrm{Mg} / \mathrm{m}^{3}$ in most of the soils), typical of Andosols except for profile 3 where $\mathrm{BD}$ is on average greater than $1 . \mathrm{pH}-\mathrm{NaF}$ indicates that except profile 3 , all soils have allophane within some of their horizons.

\subsection{Description of Sorption Isotherms}

Figures 2(a)-(f) present the adsorption isotherms of selected soil horizons for the six soils studied. The isotherm generally described by sorption in soils is the L (Langmuir) shaped isotherm, in which the slope of the curve decreases with increasing concentration. This implies that vacant adsorption sites for $\mathrm{P}$ decrease as the concentration of adsorbate $\left(\mathrm{KH}_{2} \mathrm{PO}_{4}\right)$ increases. This is explained by the high affinity of the adsorbent (soil) for the adsorptive (P) at low concentrations, which then decreases as concentration increases [1].

For profile 1, all three horizons (A, AC, and $\mathrm{Cr}$ ) follow the L-shaped isotherm. At low concentrations, soils have a high affinity for $\mathrm{P}$ and at these low concentrations; the gradient of the isotherm is very steep. As binding sites become occupied due to increase in concentration, affinity for $\mathrm{P}$ reduces with corresponding decrease in gradient of the isotherm. For profile 2, the $\mathrm{A}$ and $\mathrm{AB}$ horizons with very high OC contents follow the H-type (high-affinity) isotherms indicative of strong adsorbate-adsorptive interactions with the adsorbent. The $2 \mathrm{C}$ and $4 \mathrm{C}$ horizons follow the $\mathrm{C}$-type isotherm whereby adsorptive ions are distributed between the interfacial phase and the bulk solution phase without any specific bonding between the adsorbent and adsorbate [1]. That is, it describes partitioning, which suggests interaction between a generally hydrophobic adsorbate with a hydrophobic adsorbent [26]. In profile 3, all horizons follow the L-shaped isotherm (Langmuir). Profiles 4, 5, and 6, follow the L-shaped isotherm in all horizons.

Generally, in sorption studies, equilibrium is seldom attained especially in soils which have multi-component systems [26]. Furthermore, variability in soils 
Table 2. Selected physico-chemical properties of the six soils studied.

\begin{tabular}{|c|c|c|c|c|c|c|c|c|c|c|c|c|}
\hline $\begin{array}{l}\text { Horizon/ } \\
\text { depth }(\mathrm{cm})\end{array}$ & $\begin{array}{l}\text { Clay } \\
(\%)\end{array}$ & $\begin{array}{l}\text { Silt } \\
(\%)\end{array}$ & $\begin{array}{c}\text { Sand } \\
(\%)\end{array}$ & $\begin{array}{c}\text { Textural } \\
\text { class }\end{array}$ & $\begin{array}{c}\mathrm{BD} \\
\left(\mathrm{Mg} / \mathrm{m}^{3}\right)\end{array}$ & $\begin{array}{c}\text { Alloph } \\
(\%)\end{array}$ & $\begin{array}{c}\text { Ferrih } \\
(\%)\end{array}$ & $\mathrm{Al} / \mathrm{Si}$ & $\mathrm{pH}-\mathrm{H}_{2} \mathrm{O}$ & $\mathrm{pH}-\mathrm{KCl}$ & $\mathrm{pH}-\mathrm{NaF}$ & OC (\%) \\
\hline \multicolumn{13}{|l|}{ Profile 1} \\
\hline$A(0-65)$ & 16 & 45 & 39 & $\mathrm{~L}$ & 0.86 & 6.0 & 4.5 & 1.34 & 6.6 & 5.1 & 11.7 & 3.06 \\
\hline $\mathrm{AC}(65-95)$ & 17 & 58 & 25 & SiL & 0.99 & 5.0 & 4.5 & 1.54 & 6.5 & 5.0 & 11.4 & 2.64 \\
\hline $\mathrm{Cr}(95-170)$ & 17 & 36 & 47 & $\mathrm{~L}$ & 0.79 & 3.9 & 4.6 & 1.31 & 6.8 & 5.1 & 11.0 & 1.29 \\
\hline \multicolumn{13}{|l|}{ Profile 2} \\
\hline $\mathrm{A}(0-40)$ & 32 & 13 & 55 & SCL & 0.50 & 11.0 & 6.7 & 2.00 & 6.1 & 4.4 & 12.4 & 5.29 \\
\hline $\mathrm{AC}(40-50)$ & 21 & 43 & 36 & $\mathrm{~L}$ & 0.62 & 21.2 & 9.3 & 2.10 & 6.6 & 5.1 & 12.5 & 4.76 \\
\hline $1 C(50-100)$ & 6 & 12 & 82 & LS & 0.69 & nd & nd & nd & 7.1 & 5.5 & 11.6 & 2.60 \\
\hline $2 \mathrm{C}(100-130)$ & 5 & 25 & 70 & SL & 0.69 & nd & nd & nd & 7.3 & 6.0 & 11.2 & 0.49 \\
\hline $3 C(130-170)$ & 2 & 16 & 82 & LS & 0.68 & nd & nd & nd & 7.0 & 6.1 & 11.2 & 0.40 \\
\hline 4C (170 - 205) & 2 & 15 & 83 & LS & 0.67 & nd & nd & nd & 7.3 & 6.1 & 10.9 & 0.47 \\
\hline \multicolumn{13}{|l|}{ Profile 3} \\
\hline Ap $(0-20)$ & 18 & 49 & 33 & $\mathrm{~L}$ & 0.96 & 0.4 & 1.9 & -1.52 & 7.0 & 5.6 & 10.2 & 2.79 \\
\hline $\mathrm{AB}(20-46)$ & 30 & 25 & 45 & SCL & 1.10 & 0.2 & 1.6 & -9.80 & 5.6 & 4.3 & 10.2 & 1.57 \\
\hline $\mathrm{Bw}_{1}(46-82)$ & 30 & 37 & 33 & CL & 1.12 & nd & nd & nd & 5.3 & 4.2 & 10.5 & 1.03 \\
\hline $\mathrm{Bw}_{2}(82-123)$ & 29 & 47 & 24 & CL & 1.17 & 0.5 & 1.2 & -0.52 & 5.1 & 4.2 & 10.4 & 0.66 \\
\hline $\mathrm{BC}(123-180)$ & 17 & 58 & 25 & SiLS & 1.18 & nd & nd & nd & 5.3 & 4.0 & 10.4 & 0.49 \\
\hline $\mathrm{Cr}(180-220)$ & 17 & 48 & 35 & $\mathrm{~L}$ & 1.16 & 0.6 & 1.0 & 1.56 & 5.4 & 3.9 & 10.4 & 0.31 \\
\hline \multicolumn{13}{|l|}{ Profile 4} \\
\hline A $(4-27)$ & 21 & 43 & 36 & $\mathrm{~L}$ & 0.70 & 18.8 & 5.8 & 1.75 & 6.2 & 4.6 & 11.5 & 6.37 \\
\hline $\mathrm{Bw}(27-50)$ & 21 & 44 & 34 & $\mathrm{~L}$ & 0.87 & 24.0 & 6.0 & 1.82 & 6.4 & 5.0 & 11.4 & 4.37 \\
\hline $\mathrm{BC}(50-67)$ & 19 & 26 & 55 & SL & 0.86 & 19.5 & 6.3 & 1.54 & 6.8 & 5.7 & 11.3 & 1.73 \\
\hline $1 C(67-86)$ & 3 & 2 & 95 & $S$ & 0.92 & nd & nd & nd & 7.0 & 5.5 & 10.9 & 0.20 \\
\hline $2 C(86-100)$ & 10 & 13 & 77 & SL & 0.86 & 15.6 & 6.5 & 1.21 & 7.1 & 5.9 & 11.0 & 0.92 \\
\hline $3 C(100-122)$ & 3 & 2 & 95 & S & 0.95 & nd & nd & nd & 7.3 & 5.7 & 10.6 & 0.44 \\
\hline $4 \mathrm{C}(122-130)$ & 7 & 9 & 84 & LS & 1.08 & 8.7 & 4.3 & 1.12 & 7.1 & 6.0 & 10.8 & 0.70 \\
\hline $5 C(130-180)$ & 2 & 3 & 95 & S & 0.90 & nd & nd & nd & 7.3 & 6.0 & 10.1 & 0.12 \\
\hline \multicolumn{13}{|l|}{ Profile 5} \\
\hline$A_{c}(8-47)$ & 9 & 24 & 67 & SL & 0.57 & 15.9 & 6.9 & 1.30 & 6.1 & 4.5 & 10.4 & 5.57 \\
\hline $\mathrm{Cr}_{1}(47-132)$ & 8 & 26 & 67 & SL & 0.93 & 16.8 & 6.9 & 1.43 & 6.3 & 5.0 & 11.0 & 3.56 \\
\hline $\mathrm{Cr}_{2}(132-220)$ & 6 & 26 & 68 & SL & 0.90 & 33.8 & 9.2 & 1.44 & 6.6 & 5.3 & 11.0 & 0.99 \\
\hline \multicolumn{13}{|l|}{ Profile 6} \\
\hline A $(0-45)$ & 12 & 31 & 57 & SL & 0.65 & 20.5 & 7.8 & 1.41 & 7.3 & 6.0 & 10.6 & 5.70 \\
\hline $\operatorname{Cr}(45-60)$ & 12 & 19 & 69 & SL & 0.85 & nd & nd & nd & 7.1 & 6.2 & 10.3 & 0.62 \\
\hline $2 \mathrm{Bw}(90-130)$ & 15 & 40 & 45 & $\mathrm{~L}$ & 0.86 & 10.8 & 8.8 & 0.85 & 7.2 & 6.2 & 10.3 & 1.64 \\
\hline $2 \mathrm{Cr}_{2}(130-180)$ & 9 & 9 & 82 & LS & 0.91 & 7.7 & 7.7 & 0.56 & 7.2 & 6.2 & 10.1 & 0.32 \\
\hline
\end{tabular}

nd $=$ not determined, Alloph $=$ allophane, Ferrih $=$ ferrihydrite. 

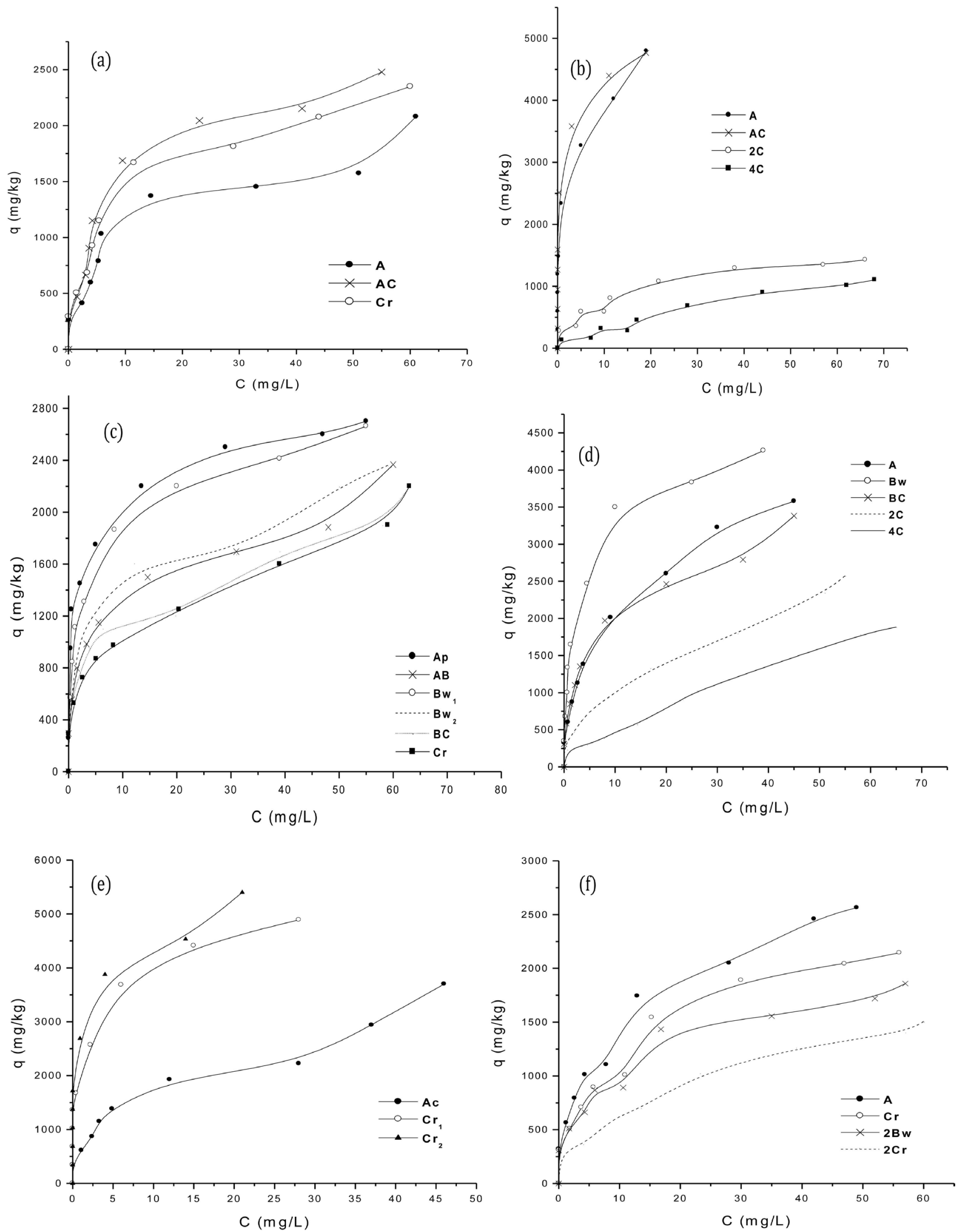

Figure 2. Adsorption isotherms of selected horizons for the six soils studied; (a) profile 1, (b) profile 2, (c) profile 3, (d) profile 4, (e) profile 5 , (f) profile 6 . 
especially when very small quantities of soil samples are used for laboratory analysis is easily observed. Further, when carrying out equilibration studies over long durations (between 16 and 24 hours) and for several days (such as in kinetics studies), often temperatures are not constant throughout. The above observations explain in part the irregular variations in sorption isotherms.

\subsection{Relationship between $P$ Sorption, Clay Content, OM Content, $\mathrm{pH}-\mathrm{NaF}$, and $\mathrm{pH}-\mathrm{H}_{2} \mathrm{O}$}

Correlations between the soil characteristics and adsorbed $\mathrm{P}$ are summarized in Table 3. The selection of these properties was based on their relevance in such studies in prior investigations [27].

Table 3. Correlations between soil properties and $\mathrm{P}$ sorbed.

\begin{tabular}{|c|c|c|c|c|c|c|c|c|c|c|c|c|}
\hline & $\mathrm{pH}-\mathrm{H}_{2} \mathrm{O}$ & $\mathrm{pH}-\mathrm{KCl}$ & $\mathrm{pH}-\mathrm{NaF}$ & $\begin{array}{c}\mathrm{BD} \\
\left(\mathrm{Mg} / \mathrm{m}^{3}\right)\end{array}$ & $\begin{array}{l}\text { Sand } \\
(\%)\end{array}$ & $\begin{array}{l}\text { Silt } \\
(\%)\end{array}$ & $\begin{array}{l}\text { Clay } \\
(\%)\end{array}$ & $\begin{array}{l}\mathrm{OM} \\
(\%)\end{array}$ & $\begin{array}{c}\text { P sorbed } \\
(\mathrm{mg} / \mathrm{kg})\end{array}$ & $\begin{array}{c}\text { Alloph } \\
(\%)\end{array}$ & $\begin{array}{c}\text { Ferrihy } \\
(\%)\end{array}$ & $\mathrm{Al} / \mathrm{Si}$ \\
\hline $\mathrm{pH}-\mathrm{H}_{2} \mathrm{O}$ & 1 & & & & & & & & & & & \\
\hline $\mathrm{pH}-\mathrm{KCl}$ & $.934^{* *}$ & 1 & & & & & & & & & & \\
\hline $\mathrm{pH}-\mathrm{NaF}$ & 0.069 & -0.132 & 1 & & & & & & & & & \\
\hline $\mathrm{BD}\left(\mathrm{Mg} / \mathrm{m}^{3}\right)$ & -0.454 & -0.225 & $-0.518^{\star}$ & 1 & & & & & & & & \\
\hline Sand (\%) & 0.449 & 0.462 & -0.283 & -0.326 & 1 & & & & & & & \\
\hline Silt (\%) & -0.240 & -0.271 & 0.171 & 0.347 & $-0.886^{\star *}$ & 1 & & & & & & \\
\hline Clay (\%) & $-0.542^{\star}$ & $-0.517^{\star}$ & 0.309 & 0.095 & $-0.599^{\star}$ & 0.160 & 1 & & & & & \\
\hline $\mathrm{OM}(\%)$ & 0.129 & -0.084 & $0.505^{*}$ & $-0.785^{\star *}$ & -0.016 & -0.010 & 0.054 & 1 & & & & \\
\hline P sorbed $(\mathrm{mg} / \mathrm{kg})$ & 0.103 & 0.026 & $0.506^{*}$ & $-0.509^{*}$ & 0.345 & -0.321 & -0.179 & 0.476 & 1 & & & \\
\hline Alloph (\%) & 0.425 & 0.373 & 0.327 & $-0.489^{\star}$ & 0.360 & -0.190 & -0.437 & 0.440 & $0.820^{\star *}$ & 1 & & \\
\hline Ferrihy (\%) & $0.764^{* *}$ & $0.701^{\star *}$ & 0.269 & $-0.669^{* *}$ & $0.552^{*}$ & -0.374 & $-0.529^{\star}$ & 0.374 & $0.637^{\star *}$ & $0.764^{\star *}$ & 1 & \\
\hline $\mathrm{Al} / \mathrm{Si}$ & 0.371 & 0.251 & 0.422 & -0.436 & 0.045 & 0.182 & -0.412 & 0.287 & 0.330 & 0.424 & 0.469 & 1 \\
\hline
\end{tabular}

**. Correlation is significant at the 0.01 level (2-tailed), $\mathrm{P} \leq 0.01$; ${ }^{*}$. Correlation is significant at the 0.05 level (2-tailed), $\mathrm{P} \leq 0.05$.

Maximum amount of P sorbed ranged from 2080 to $5402 \mathrm{mg} / \mathrm{kg}$ (Table 4) for the $P$ equilibrium concentrations established.

However, the adsorption curves (Figure 2) indicate that these soils would adsorb more $\mathrm{P}$ if the concentrations of the equilibrating solution were increased.

$\mathrm{pH}-\mathrm{NaF}$ is an indication of the presence of amorphous materials or allophanes in volcanic ash soils if the $\mathrm{pH}-\mathrm{NaF}$ test gives a value of 9.5 or more [28]. $\mathrm{pH}-\mathrm{NaF}$ values indicate that all soils might contain allophane. Profile 3 (aluandic Cambisol), with the lowest $\mathrm{pH}-\mathrm{NaF}$ values and an average of 10.4, is the most weathered of all the soils with very low concentrations of allophane (less than 1\%). Pooled data for the soils show that there is a positive and significant correlation between $\mathrm{P}$ sorbed and $\mathrm{pH}-\mathrm{NaF}$. This behaviour indicates that allophane is likely a dominant component of these soils and is responsible for the adsorption of $\mathrm{P}$. However, from the phosphate-binding groups in soils, such as, Al-O-Si, R-COO-Al 
Table 4. Parameters of various equilibrium-based models.

\begin{tabular}{|c|c|c|c|c|c|c|c|c|c|}
\hline \multirow{2}{*}{$\begin{array}{l}\text { Selected profile } \\
\text { horizons }\end{array}$} & \multirow{2}{*}{$\begin{array}{c}\text { P sorbed } \\
c\end{array}$} & \multicolumn{2}{|c|}{ Langmuir } & \multicolumn{2}{|c|}{ Freundlich } & \multicolumn{2}{|c|}{ Van Huay } & \multicolumn{2}{|c|}{ Temkin } \\
\hline & & $\begin{array}{c}b \\
(\mathrm{mg} / \mathrm{kg})\end{array}$ & $\begin{array}{c}k \\
(\mathrm{~L} / \mathrm{mg})\end{array}$ & $\begin{array}{c}1 / n \\
(\mathrm{~L} / \mathrm{kg})\end{array}$ & $K_{d}$ & $\begin{array}{c}n \\
(\mathrm{~L} / \mathrm{kg})\end{array}$ & $\begin{array}{c}m \\
\left(\mathrm{mg}^{2} / \mathrm{kg}^{2}\right)\end{array}$ & $\begin{array}{c}a \\
(\mathrm{mg} / \mathrm{kg})\end{array}$ & $\begin{array}{c}b \\
(\mathrm{~mL} / \mathrm{g})\end{array}$ \\
\hline A & 2080 & 2018 & 0.124 & 0.333 & 462 & 12.0 & 22.9 & 231 & 194 \\
\hline $\mathrm{AC}$ & 2479 & 2606 & 0.192 & 0.436 & 486 & 36.4 & 15.3 & 324 & 255 \\
\hline $\mathrm{Cr}$ & 2350 & 2428 & 0.206 & 0.458 & 415 & 29.7 & 16.5 & 286 & 273 \\
\hline A & 4799 & 4476 & 2.169 & 0.236 & 2070 & 13.1 & 50.0 & 959 & 782 \\
\hline $\mathrm{AC}$ & 4767 & 4435 & 3.263 & 0.128 & 2931 & 8.0 & 54.7 & 760 & 1050 \\
\hline $2 \mathrm{C}$ & 2690 & 2014 & 0.062 & 0.357 & 334 & 16.9 & 16.4 & 210 & 45 \\
\hline $4 \mathrm{C}$ & 2025 & 2976 & 0.011 & 0.59 & 89 & - & - & 180 & -192 \\
\hline Ap & 1686 & 2360 & 0.040 & 0.467 & 229 & - & - & 361 & 31 \\
\hline $\mathrm{AB}$ & 2367 & 2224 & 0.250 & 0.283 & 676 & 13.4 & 18.9 & 349 & 631 \\
\hline $\mathrm{Bw}_{1}$ & 2663 & 2662 & 0.529 & 0.287 & 927 & 15.0 & 22.4 & 414 & 994 \\
\hline $\mathrm{Bw}_{2}$ & 2361 & 2100 & 0.366 & 0.259 & 752 & 11.5 & 20.8 & 317 & 747 \\
\hline $\mathrm{BC}$ & 2197 & 1691 & 0.282 & 0.22 & 659 & 9.3 & 19.3 & 241 & 620 \\
\hline $\mathrm{Cr}$ & 2143 & 1600 & 0.231 & 0.467 & 231 & 10.0 & 17.5 & 262 & 462 \\
\hline A & 3578 & 3784 & 0.189 & 0.437 & 719 & 34.7 & 15.2 & 748 & 526 \\
\hline $\mathrm{Bw}$ & 4261 & 4373 & 0.548 & 0.355 & 1334 & 28.2 & 24.0 & 734 & 1553 \\
\hline $\mathrm{BC}$ & 3382 & 3339 & 0.267 & 0.368 & 826 & 25.0 & 18.4 & 591 & 798 \\
\hline $2 \mathrm{C}$ & 2575 & 2270 & 0.112 & 0.431 & 368 & 24.1 & 11.2 & 496 & -7 \\
\hline $4 \mathrm{C}$ & 1883 & 2919 & 0.024 & 0.723 & 92 & - & - & 630 & 911 \\
\hline $\mathrm{A}_{\mathrm{c}}$ & 3699 & 3580 & 0.148 & 0.436 & 627 & 34.1 & 13.7 & 732 & 297 \\
\hline $\mathrm{Cr}_{1}$ & 4893 & 4843 & 1.507 & 0.262 & 2138 & 29.5 & 29.5 & 789 & 2225 \\
\hline $\mathrm{Cr}_{2}$ & 5402 & 5102 & 3.791 & 0.15 & 3133 & 31.8 & 31.9 & 463 & 3417 \\
\hline A & 3261 & 2772 & 0.157 & 0.411 & 532 & 23.8 & 14.7 & 561 & 260 \\
\hline $\mathrm{Cr}$ & 2725 & 2381 & 0.122 & 0.43 & 400 & 21.0 & 13.3 & 511 & 47 \\
\hline $2 \mathrm{Bw}$ & 2638 & 1958 & 0.153 & 0.232 & 617 & 15.3 & 14.7 & 193 & 737 \\
\hline $2 \mathrm{Cr}$ & 2445 & 1760 & 0.070 & 0.332 & 330 & 24.1 & 7.7 & 237 & 279 \\
\hline
\end{tabular}

(organic ligands), and Al-OH groups [29], and given that exchangeable aluminium values would be low as indicated by the $\mathrm{pH}-\mathrm{H}_{2} \mathrm{O}$ values that are greater than 5.5, phosphate groups in these soils could thus be largely attributed to organic ligand binding groups. This probably explains why $\mathrm{P}$ sorption also correlates with organic matter (OM). Organic matter and allophane are known to be the key colloids in Andosols which have a high affinity for elements mainly through sorption processes [30] [31].

No correlation was observed between clay content and P sorption, though reports by [22] indicate that the amount of $\mathrm{P}$ sorbed increases with increases in clay content. Kaolinite, a major phyllosilicate clay mineral, is reported to con- 
tribute to $\mathrm{P}$ sorption at low $\mathrm{pH}$ [32]. The mechanism for such behaviour has been explained by $\mathrm{pH}$-dependent charge sites at crystal edges in kaolinite, where $\mathrm{A} 1(\mathrm{OH}) \mathrm{H}_{2} \mathrm{O}$ groups are exposed, and at low $\mathrm{pH}$, become positively charged and adsorb $\mathrm{P}$ [32]. $\mathrm{pH}-\mathrm{H}_{2} \mathrm{O}$ values in these soils vary from 6.5 - 6.8 (Profile 1), 6.1 7.3 (profile 2), 5.1 - 7.0 (profile 3), 6.2 - 7.3 (profile 4), 6.1 - 6.6 (profile 5), and 7.1 - 7.3 (profile 6). Only profile 3 has low pHs less than 5.5 at which exchangeable aluminium would be observed. This is the only profile in which $\mathrm{P}$ sorbed correlates best with clay content $(r=0.75)$, though not significant.

$\mathrm{P}$ sorption has been reported to be more closely related to the content of oxalate-extractable aluminium (corresponding to poorly ordered inorganic and organic $\mathrm{Al}$ compounds that release considerable amounts of $\mathrm{OH}$ to $\mathrm{NaF}$ solution) than to any other soil constituent [33]. The concentration of these compounds in soil could be estimated by measuring the $\mathrm{pH}$ of a $\mathrm{NaF}$ extract. Equally, other studies by the latter authors on some west Australian soils indicate that well crystalline aluminium and iron oxides, clay minerals and other soil constituents are of secondary importance in determining $\mathrm{P}$ sorption and that most $\mathrm{P}$ sorption is associated with poorly ordered and organically complexed forms of $\mathrm{Al}$.

This may also explain why $\mathrm{P}$ sorption of these soils significantly correlates with $\mathrm{pH}-\mathrm{NaF}$ and $\mathrm{OM}$ but does not with clay content.

In a review on the relationship between $\mathrm{P}$ availability and iron oxides and OM, in some highly weathered Brazilian Ferralsols, [7] reported that iron oxides and $\mathrm{OM}$ are the soil constituents most strongly affecting the reactions and rate of phosphorus adsorption and desorption of P. Given that OM is an important influential factor on chemical, physical and biological soil properties, [7] observed that adsorption of organic functional groups onto iron oxides can promote anion (phosphate) adsorption through cation bridges $\left(\mathrm{Al}^{3+}\right.$ and $\mathrm{Fe}^{3+}$ ). Though the soils in this study are relatively less weathered, they occur in environments (humid tropics) which have similar soil chemical processes, and similar properties associated with their variable charge nature. This is in agreement with the significant correlation between $\mathrm{P}$ sorption and OM in this study. In view of the foregoing, [7] assert that fertilizer recommendations based on soil buffering categories established in terms of clay contents alone may be erroneous.

Observations in this study of a positive correlation between phosphate adsorption and OM content are in agreement with reports by [34].

Reference [35], in their study, "Organic matter effects on phosphorus sorption in sandy soils" in west and south west Poland, also observed that removal of OM from soil reduced phosphate adsorption. The effect of OM on phosphate adsorption is indirect; the interactions between OM and oxides of iron and aluminium inhibit their crystallization thereby increasing their phosphate adsorption capacity [34]. The high $\mathrm{pH}-\mathrm{NaF}$ indicates that active aluminium is present, but because the $\mathrm{pH}$-values of most of the soils are within the ranges for which aluminium is not soluble (except profile 3 ), it is probable the large surface area of allophane exposes considerable amounts of aluminium on its surface, capable of 
fixing high $\mathrm{P}$ [36] [37]. Correlations between $\mathrm{pH}-\mathrm{H}_{2} \mathrm{O}$ and $\mathrm{P}$ sorbed, for profiles $1,2,4,5$, and 6 , which have $\mathrm{pHs}$ greater than 6 indicate that OM can increase $\mathrm{P}$ sorption. This is in agreement with results of [37] who reported that, at a soil $\mathrm{pH}>6.0$, soil $\mathrm{OM}$ increases $\mathrm{P}$ sorption.

\subsection{Relationship between P Sorbed, Allophane Content, and Ferrihydrite Content}

Influence of amorphous materials in soils notably allophane and ferrihydrite has been reported [38]. Table 2 shows that all profiles contain allophane and ferrihydrite, except profile 3. Allophane and ferrihydrite correlate positively and significantly with amount of $\mathrm{P}$ sorbed indicating that these amorphous species greatly contribute to $\mathrm{P}$ sorption. Allophane has a higher affinity for phosphate compared to ferrihydrite [38] and the higher concentration of allophane content compared to that of ferrihydrite in the studied soils indicates that its effect on $\mathrm{P}$ sorption is greater. This high $\mathrm{P}$ sorption is probably due to its high surface area [36].

The net positive charge of amorphous silicates at prevailing soil $\mathrm{pH}$ causes a strong adsorption of phosphate ions and the phosphate adsorption capacity increases with the $\mathrm{Al} / \mathrm{Si}$ ratio of allophane [29]. This Al/Si molar ratio, computed as $\left(\mathrm{Al}_{\mathrm{o}}-\mathrm{Al}_{\mathrm{p}}\right) /\left(\mathrm{Si}_{\mathrm{o}}\right)$ molar ratio, where ${ }_{\mathrm{o}}$ and $\mathrm{p}$ refer to oxalate and pyrophosphate extractions, respectively, which is an indication of the type of allophane (silicon or aluminium rich) [39], indicates that aluminium in allophane is more responsible for $\mathrm{P}$ sorption than silicon. The high positive and significant correlation between $\mathrm{P}$ sorbed and $\mathrm{Al}_{0}+1 / 2 \mathrm{Fe}_{\circ}$ ratio is in agreement with observations of [40], and indicates that $\mathrm{P}$ sorption will increase with increasing andic properties generally characterized by presence of short-range-order minerals, such as allophane and ferrihydrite. The high positive and significant correlation between allophane content and P sorbed $(r=0.806, P<0.01)$ and between $\mathrm{P}$ sorbed and ferrihydrite content $(r=0.669, P<0.01)$ compared to $\mathrm{OC}(\mathrm{r}=0.476, P>0.05)$ clearly indicates that these amorphous substances are the principal soil components responsible for $\mathrm{P}$ sorption. This confirms the assertion earlier made with respect to $\mathrm{pH}-\mathrm{NaF}$ as an indication of the presence of amorphous substances notably allophane [33] in these soils. Though there is no significant correlation between allophane and $\mathrm{pH}-\mathrm{NaF}$, the fact that $\mathrm{pH}-\mathrm{NaF}$ correlates with $\mathrm{P}$ sorbed and because $\mathrm{pH}-\mathrm{NaF}$ values reflect the presence or absence of allophane in the soils, $\mathrm{pH}-\mathrm{NaF}$ can be used as a fast tool to estimate $\mathrm{P}$ sorbed in these soils using the following simple linear regression Equation (7).

$$
\text { P sorbed }=782.7(\mathrm{pH}-\mathrm{NaF})-5277, \quad r=0.506^{*}
$$

The rationale for using $\mathrm{pH}-\mathrm{NaF}$ for estimating $\mathrm{P}$ sorbed is that this parameter can be easily measured in the laboratory or in the field.

However, because allophane and ferrihydrite correlate with $\mathrm{P}$ sorbed better than $\mathrm{pH}-\mathrm{NaF}$, they remain better estimators of $\mathrm{P}$ sorbed in these soils compared to $\mathrm{pH}-\mathrm{NaF}$. 


\subsection{Equilibrium-Based Models for P Sorption Description}

Plots of P sorption data following the Langmuir, Freundlich, Temkin and Van-Huay equilibrium-based models for the soil profiles and horizons studied (Figures 3-8) indicate that all four models show very good fits.
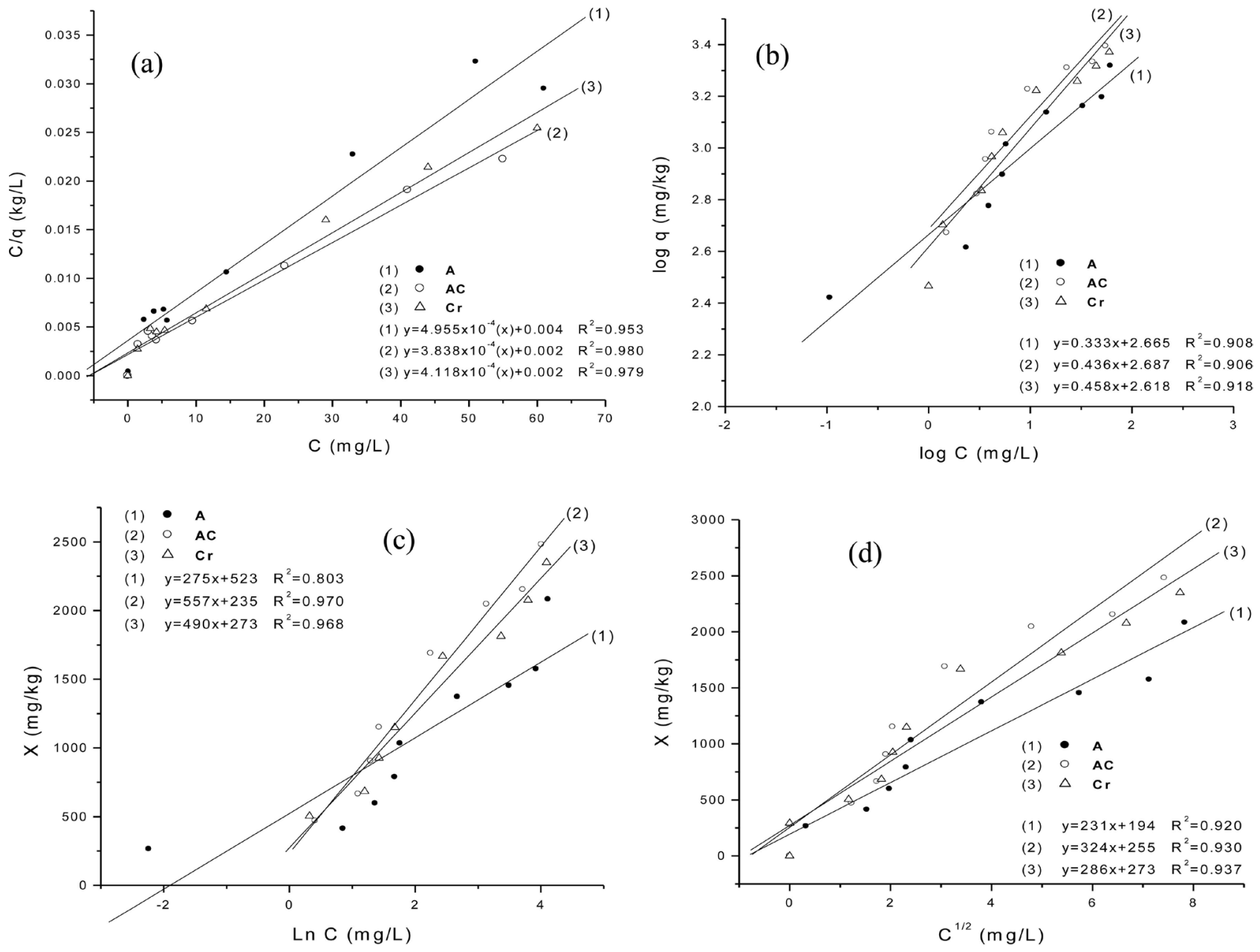

Figure 3. Equilibrium-based models for profile 1: (a) Langmuir, (b) Freundlich, (c) Temkin, and (d) Van Huay.
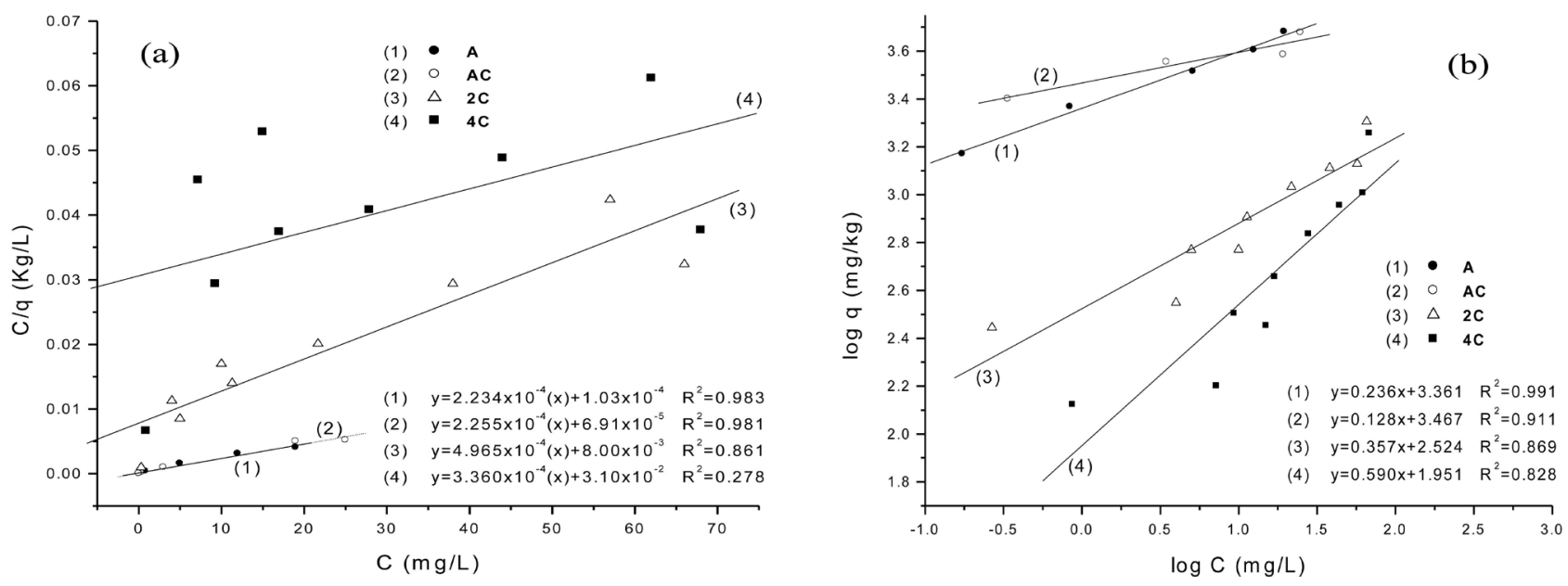

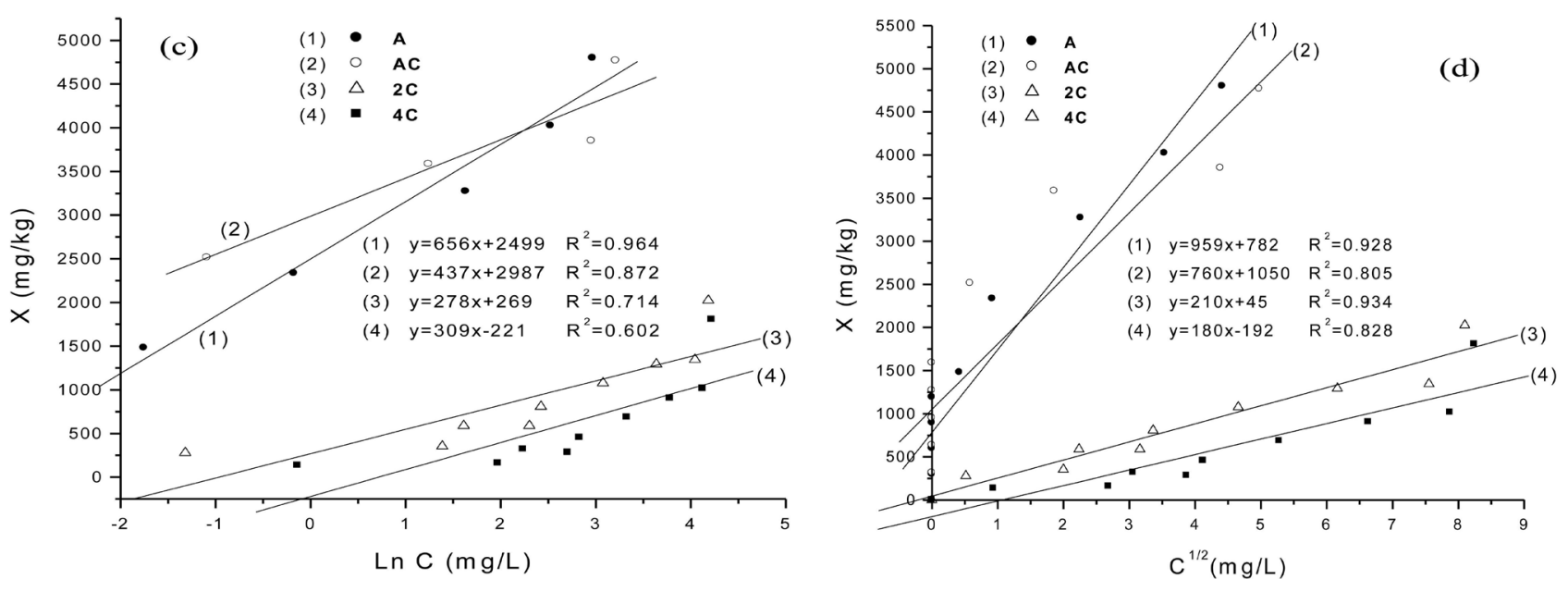

Figure 4. Equilibrium-based models for profile 2: (a) Langmuir, (b) Freundlich, (c) Temkin, and (d) Van Huay.
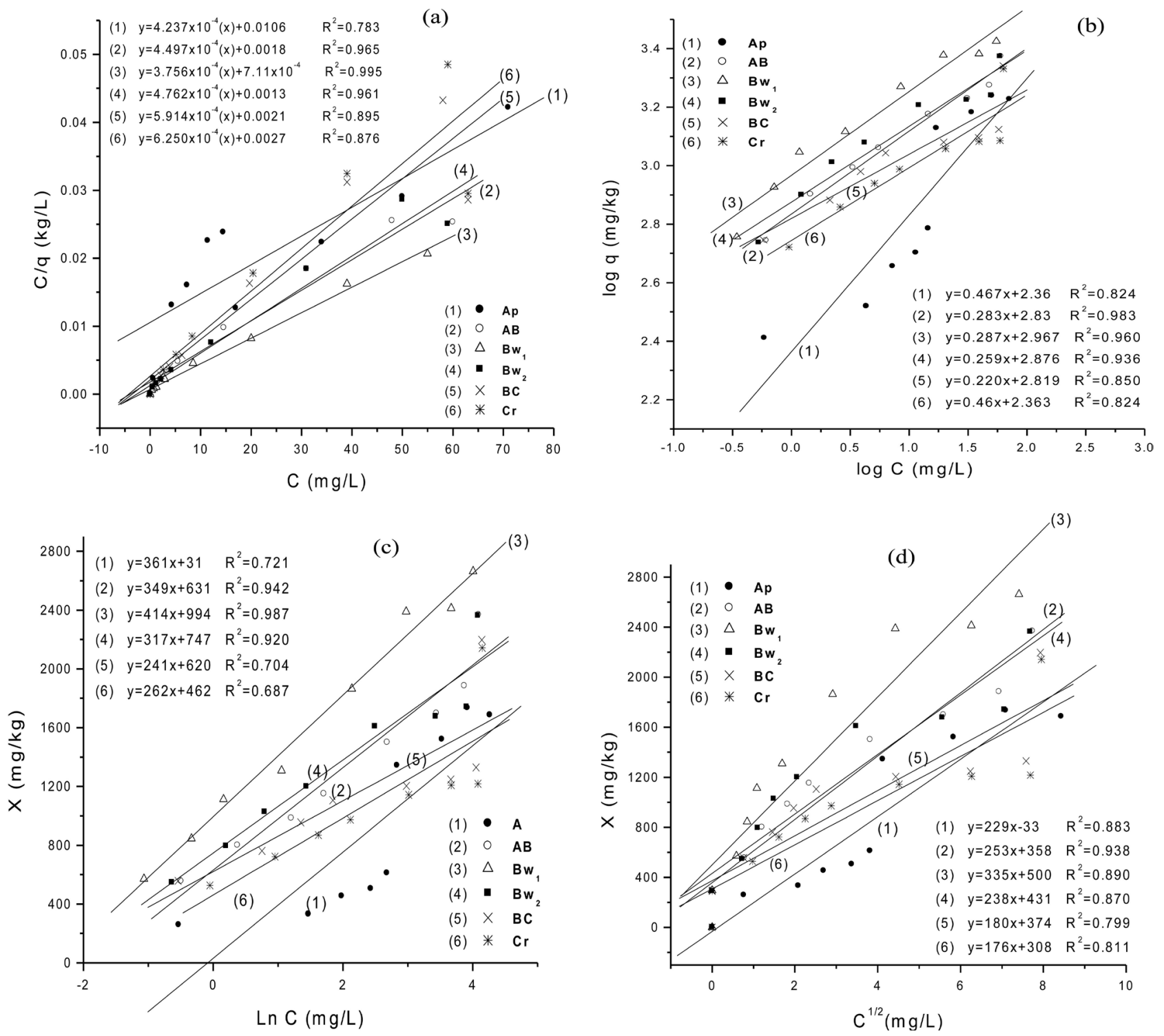

Figure 5. Equilibrium-based models for profile 3: (a) Langmuir, (b) Freundlich, (c) Temkin, and (d) Van Huay. 

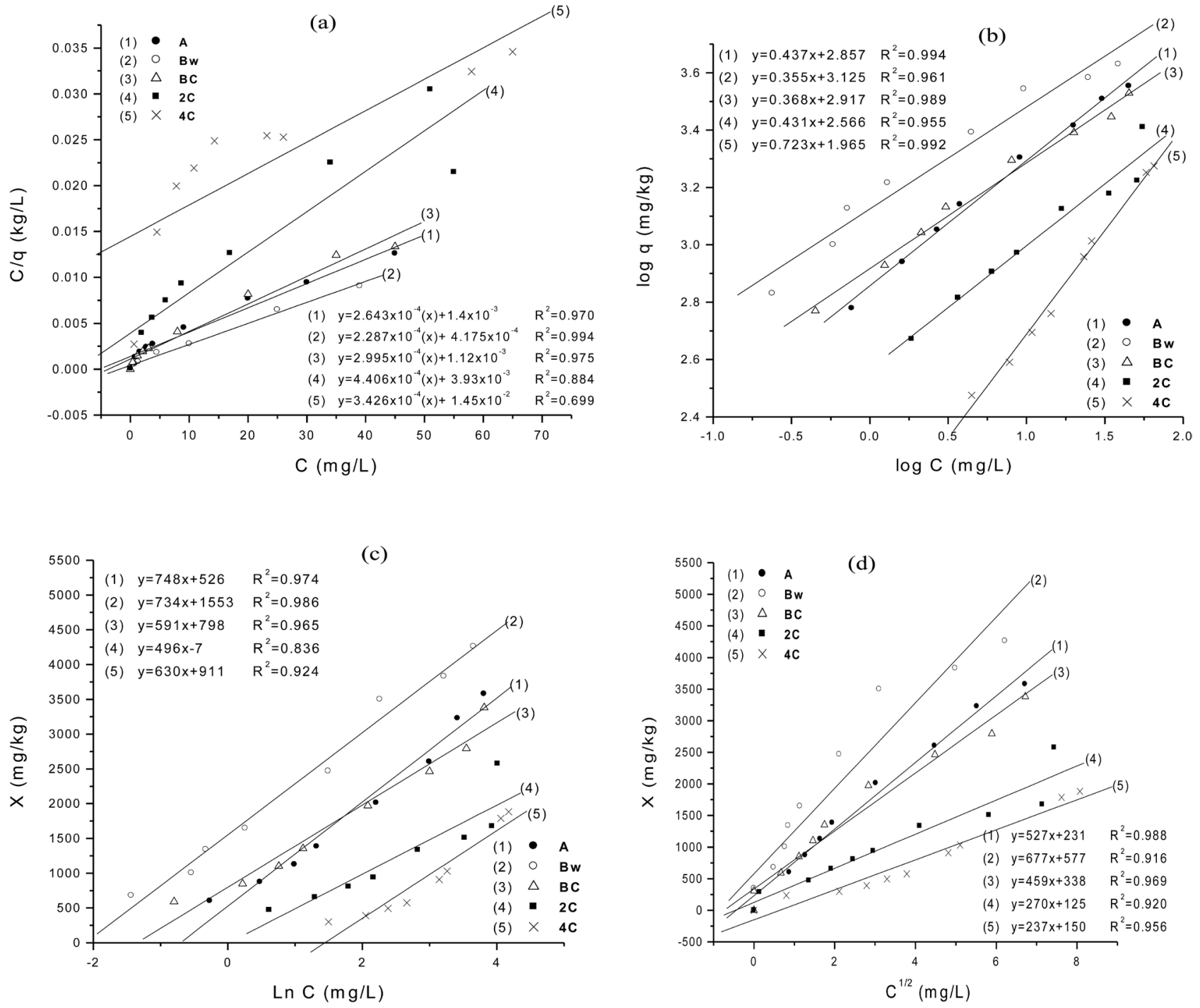

Figure 6. Equilibrium-based models for profile 4: (a) Langmuir, (b) Freundlich, (c) Temkin, and (d) Van Huay.
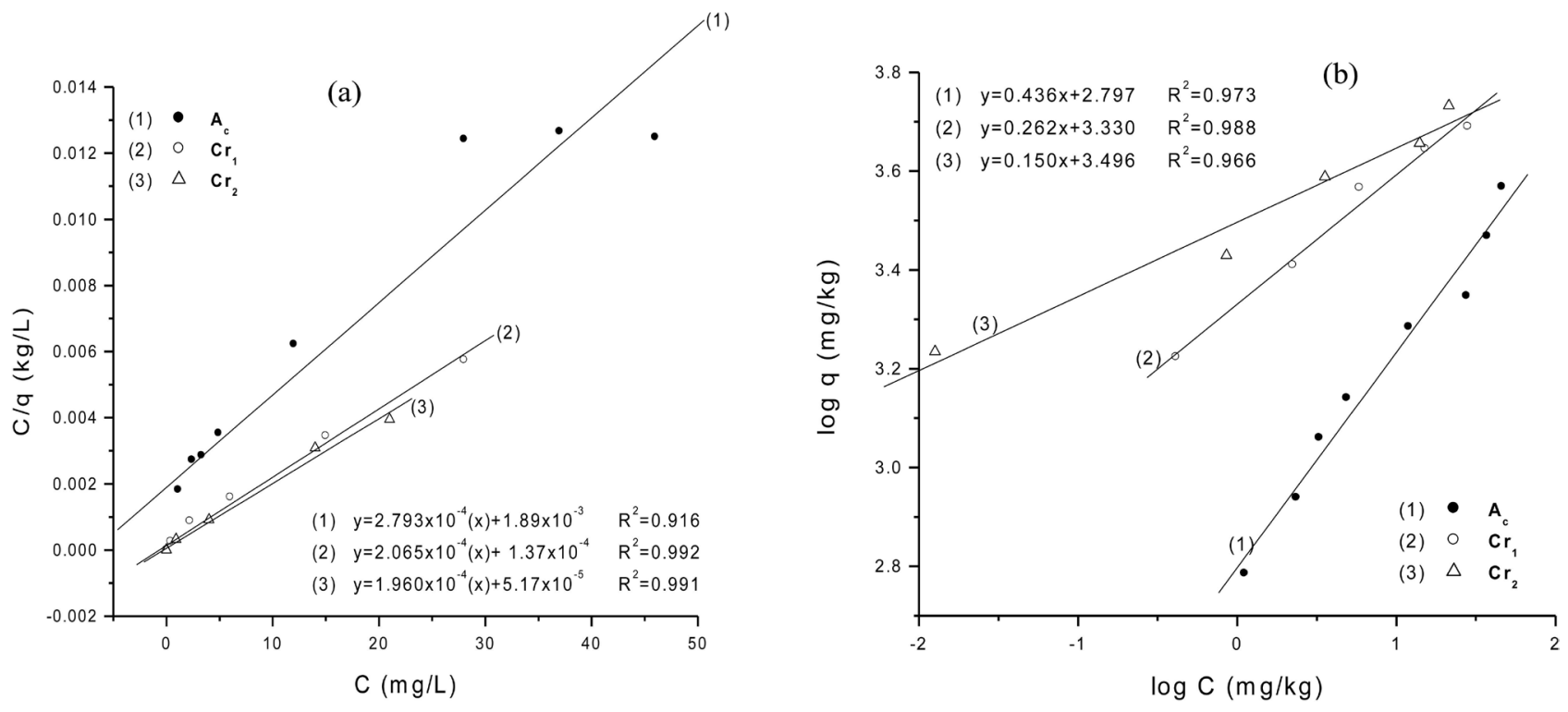

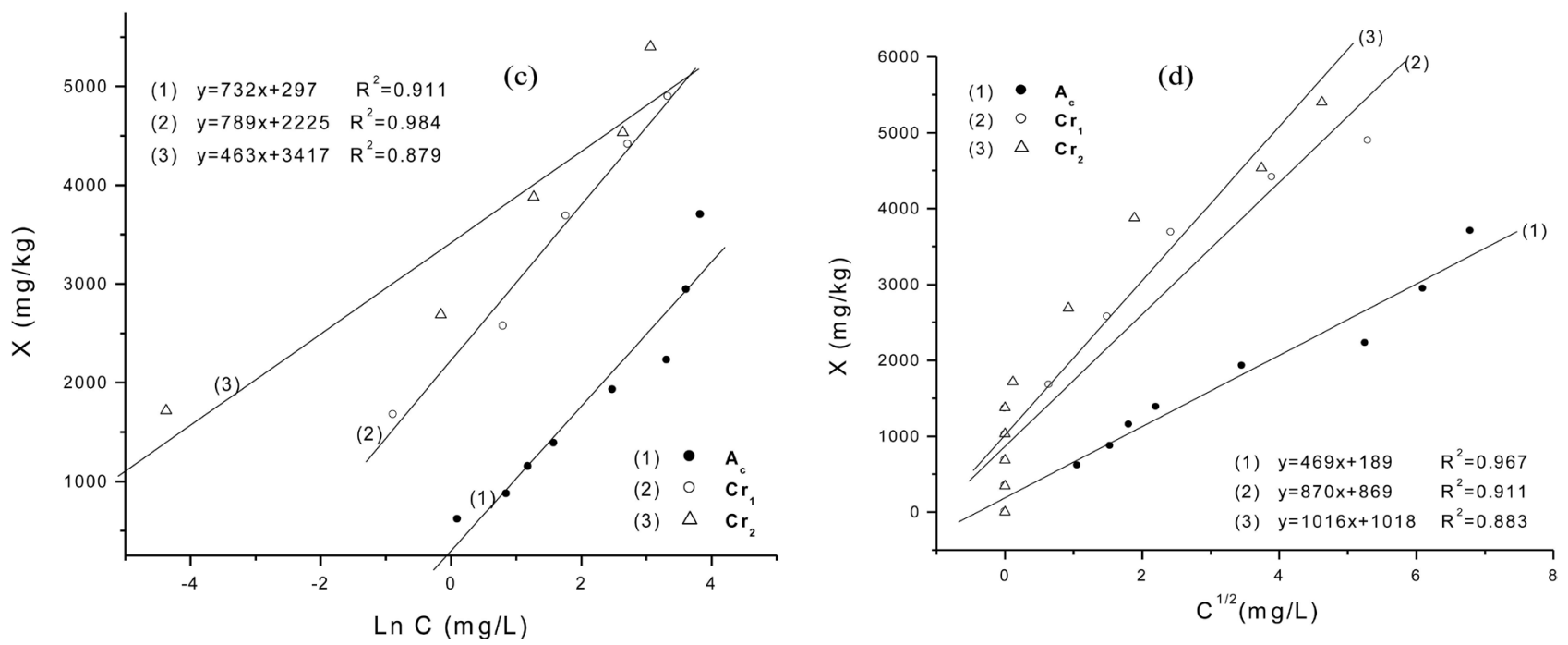

Figure 7. Equilibrium-based models for profile 5: (a) Langmuir, (b) Freundlich, (c) Temkin, and (d) Van Huay.
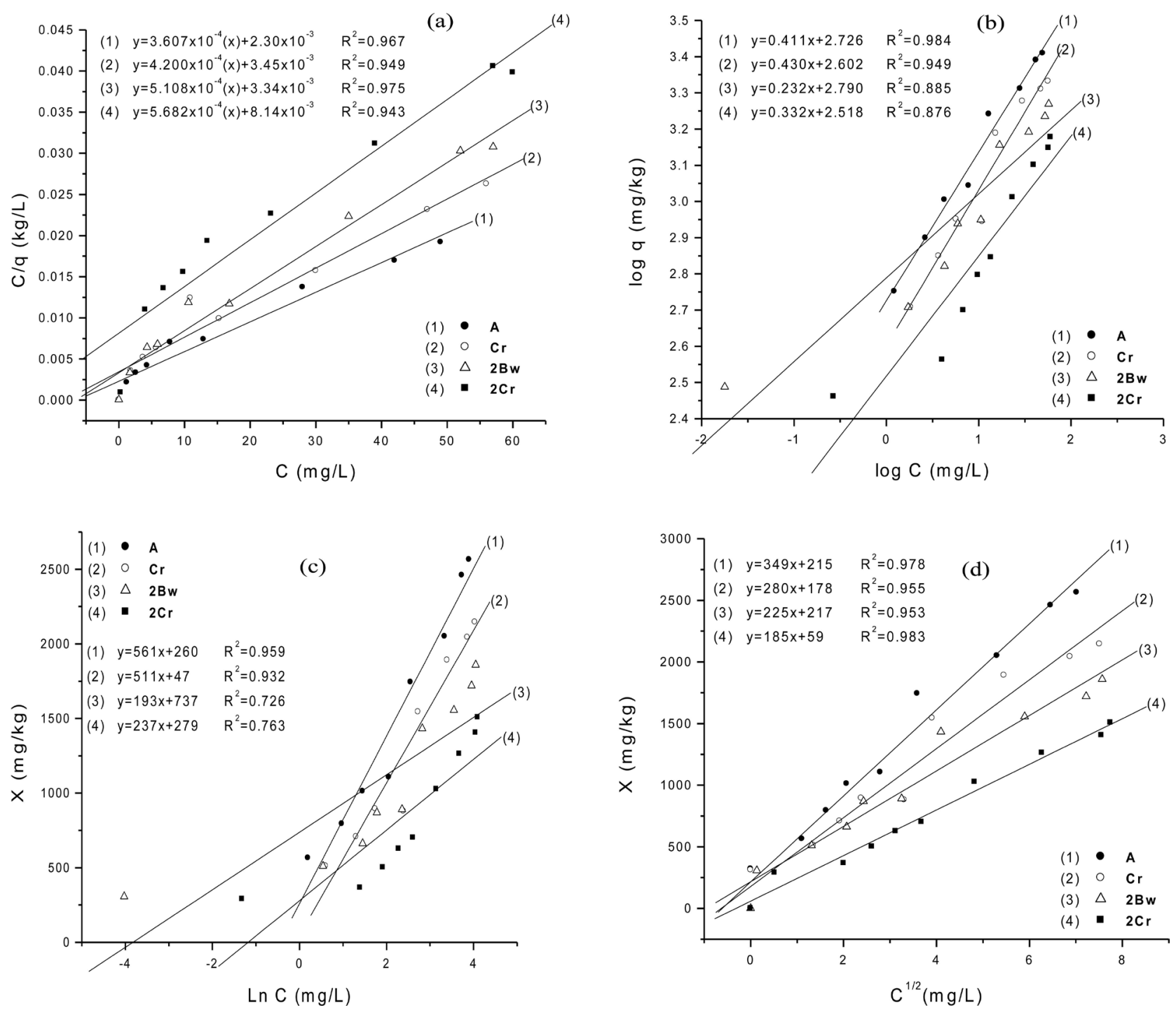

Figure 8. Equilibrium-based models for profile 6: (a) Langmuir, (b) Freundlich, (c) Temkin, and (d) Van Huay. 
Generally, the Langmuir model presents the best fit, though the coefficients of determinations are very similar for all the models. The fact that all the curves in all horizons within the profiles do not systematically follow the L-shaped type of isotherm (Figure 2) suggests that the other three models would be better indicated for some of the soils than the Langmuir model.

\subsection{Relationship between $P$ Sorption Parameters, P Sorbed, and Selected Soil Properties}

Sorption parameters for the four models used are presented in Table 4. Table 5 indicates that, $\mathrm{b}$, the maximum amount of $\mathrm{P}$ that can be sorbed increases with increase in $\mathrm{pH}-\mathrm{NaF}, \mathrm{OM}$, allophane content, ferrihydrite content, $\mathrm{Al} / \mathrm{Si}$ molar ratio, and $\mathrm{Al}_{\mathrm{o}}+1 / 2 \mathrm{Fe}_{\mathrm{o}}$ ratio. These are the same parameters that correlate with $\mathrm{P}$ sorbed. This indicates that the Langmuir equation perfectly describes $\mathrm{P}$ sorption in these soils. The constant $k$, related to the binding strength, increases with $\mathrm{pH}-\mathrm{NaF}$, allophane content, ferrihydrite content, and $\mathrm{Al}_{0}+1 / 2 \mathrm{Fe}_{\mathrm{o}}$ ratio. This implies that active aluminium as predicted by the $\mathrm{pH}-\mathrm{NaF}$ values contributes to this binding energy.

The distribution coefficient of the Freundlich model $\left(K_{d}\right)$ significantly increases with increase in $\mathrm{pH}-\mathrm{NaF}$, allophane content, ferrihydrite content, and $\mathrm{Al}_{\mathrm{o}}+1 / 2 \mathrm{Fe}_{\mathrm{o}}$ ratio.

The amount of $\mathrm{P}$ sorbed in the Temkin model increases with $\mathrm{pH}-\mathrm{NaF}, \mathrm{OM}$, allophane content and the $\mathrm{Al}_{\mathrm{o}}+1 / 2 \mathrm{Fe}_{\mathrm{o}}$ ratio. This can equally be explained by the amount of active $\mathrm{Al}$ present.

In the Van Huay model, the adsorption coefficient ( $n$ ) doesn't significantly correlate with any of the soil properties, while the constant, $m$, increases with pH-NaF and $\mathrm{Al}_{0}+1 / 2 \mathrm{Fe}_{\mathrm{o}}$ ratio.

Table 5. Summary of correlations between P sorption parameters and soil characteristics.

\begin{tabular}{|c|c|c|c|c|c|c|c|c|c|}
\hline & $c(\mathrm{mg} / \mathrm{kg})$ & $b(\mathrm{~kg} / \mathrm{L})$ & $k(\mathrm{~L} / \mathrm{mg})$ & $1 / n(\mathrm{~L} / \mathrm{kg})$ & $K_{d}$ & $n(\mathrm{~L} / \mathrm{kg})$ & $m\left(\mathrm{mg}^{2} / \mathrm{kg}^{2}\right)$ & $a(\mathrm{mg} / \mathrm{kg})$ & $b(\mathrm{~mL} / \mathrm{g})$ \\
\hline $\mathrm{c}(\mathrm{mg} / \mathrm{kg})$ & 1 & $0.972^{* *}$ & $0.812^{\star *}$ & $-0.540^{*}$ & $0.898^{* *}$ & 0.232 & $0.689^{* *}$ & $0.806^{* *}$ & $0.751^{* *}$ \\
\hline $\mathrm{pH}-\mathrm{H}_{2} \mathrm{O}$ & 0.103 & 0.050 & 0.015 & -0.027 & 0.019 & 0.301 & -0.130 & -0.068 & -0.019 \\
\hline $\mathrm{pH}-\mathrm{KCl}$ & 0.026 & -0.056 & -0.036 & -0.149 & -0.016 & 0.205 & -0.228 & -0.206 & 0.050 \\
\hline $\mathrm{pH}-\mathrm{NaF}$ & $0.506^{*}$ & $0.573^{\star}$ & $0.523^{*}$ & -0.275 & $0.547^{\star}$ & -0.091 & $0.773^{\star *}$ & $0.578^{\star}$ & 0.127 \\
\hline Sand (\%) & 0.345 & 0.243 & 0.194 & -0.140 & 0.197 & 0.291 & -0.076 & 0.172 & 0.273 \\
\hline Total Silt (\%) & -0.321 & -0.223 & -0.192 & 0.237 & -0.201 & -0.052 & -0.088 & -0.282 & -0.161 \\
\hline Clay (\%) & -0.179 & -0.129 & -0.082 & -0.112 & -0.071 & $-0.529^{\star}$ & 0.316 & 0.122 & -0.303 \\
\hline OM (\%) & 0.476 & $0.531^{\star}$ & 0.106 & 0.093 & 0.211 & 0.240 & 0.310 & $0.783^{\star *}$ & -0.101 \\
\hline Allophane (\%) & $0.820^{\star \star}$ & $0.798^{\star *}$ & $0.587^{\star}$ & -0.333 & $0.662^{* *}$ & 0.416 & 0.324 & $0.574^{\star}$ & $0.666^{\star *}$ \\
\hline $\mathrm{Al} / \mathrm{Si}$ & 0.331 & 0.315 & 0.198 & 0.118 & 0.193 & 0.266 & 0.178 & 0.281 & 0.097 \\
\hline Ferrihydrite (\%) & $0.637^{\star *}$ & $0.547^{\star}$ & $0.499^{*}$ & -0.426 & $0.535^{*}$ & 0.280 & 0.301 & 0.383 & 0.375 \\
\hline $\mathrm{Al}_{o}+1 / 2 \mathrm{Fe}_{\mathrm{o}}(\%)$ & $0.913^{* *}$ & $0.885^{* *}$ & $0.701^{* *}$ & -0.441 & $0.777^{* *}$ & 0.291 & $0.558^{*}$ & $0.733^{* *}$ & $0.604^{\star}$ \\
\hline
\end{tabular}

${ }^{* *}$ Correlation is significant at the 0.01 level (2-tailed), $\mathrm{P} \leq 0.01$; ${ }^{*}$ Correlation is significant at the 0.05 level (2-tailed), $P \leq 0.05$. 
These correlations show that model parameters that directly explain or inform on adsorption are better observed for the Langmuir, Freundlich, and Temkin models.

Because the amount of $\mathrm{P}$ sorbed in the Temkin model has values that are very different from the actual $\mathrm{P}$ sorbed values, the Temkin model would not be considered a good model for evaluating P sorption in these soils. Thus, following the relationships between sorption parameters and soil properties, the Langmuir and Freundlich equilibrium-based models best explain P sorption in these soils.

\subsection{Estimation of P Sorbed Using Multiple Linear Regression and Applications}

Based on the fact that $\mathrm{P}$ sorbed is related to $\mathrm{pH}-\mathrm{NaF}, \mathrm{OM}$, allophane content, and ferrihydrite content, two multiple regression equations have been proposed for the estimation of $\mathrm{P}$ sorbed in these soils; the first Equation (8) relates $\mathrm{OM}$ and $\mathrm{pH}-\mathrm{NaF}$ to $\mathrm{P}$ sorbed.

$$
\text { P sorbed }=103(\mathrm{OM})+649(\mathrm{pH}-\mathrm{NaF})-4447, \quad R^{2}=0.371
$$

The rationale for using these two parameters ( $\mathrm{OM}$ and $\mathrm{pH}-\mathrm{NaF})$ is based on their ease of determination in soils.

Estimated P sorbed using this equation significantly correlates with the experimentally determined P sorbed (Figure 9).

Paired sample t-test performed on the data sets showed that the means are statistically equal ( $t=0.017, p=0.986$ at the $95 \%$ confidence level).

The second multiple regression Equation (9), relates allophane (Alloph) and ferrihydrite (Ferrih) contents to $P$ sorbed:

$$
\text { P sorbed }=92.4(\text { Alloph })+11.2(\text { Ferrih })+2107, \quad R^{2}=0.67
$$

Estimated P sorbed using this equation significantly correlates with the experimentally determined $\mathrm{P}$ sorbed (Figure 10).

Paired sample t-test performed on the data sets show that the means are statistically equal ( $t=-0.834, p=0.415$ at the $95 \%$ confidence level).

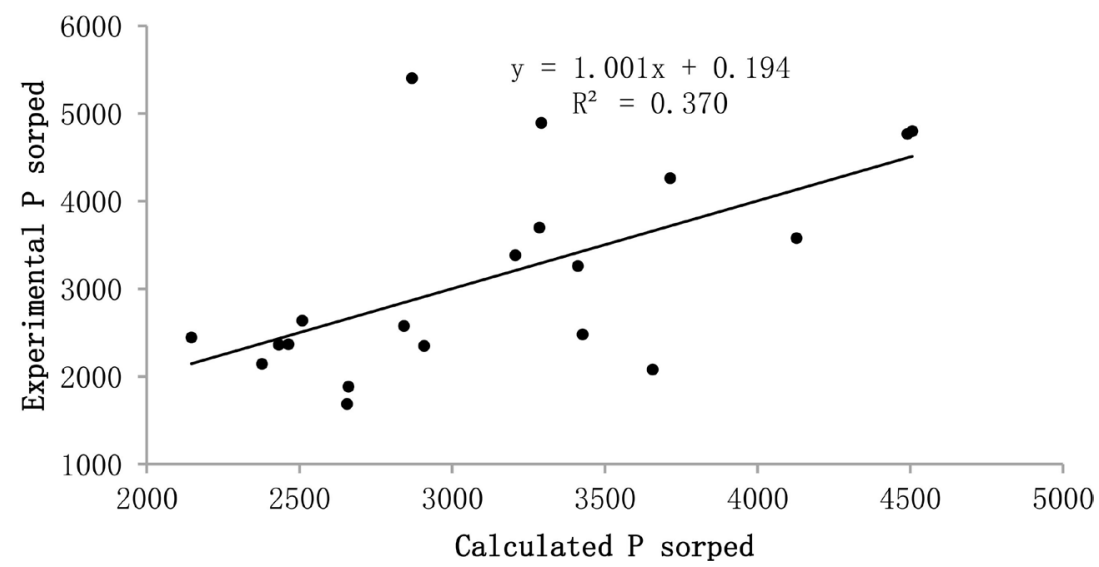

Figure 9. Correlation between experimentally determined P-sorbed and estimated P-sorbed using $\mathrm{OM}$ and $\mathrm{pH}-\mathrm{NaF}$ (Equation (8)). 


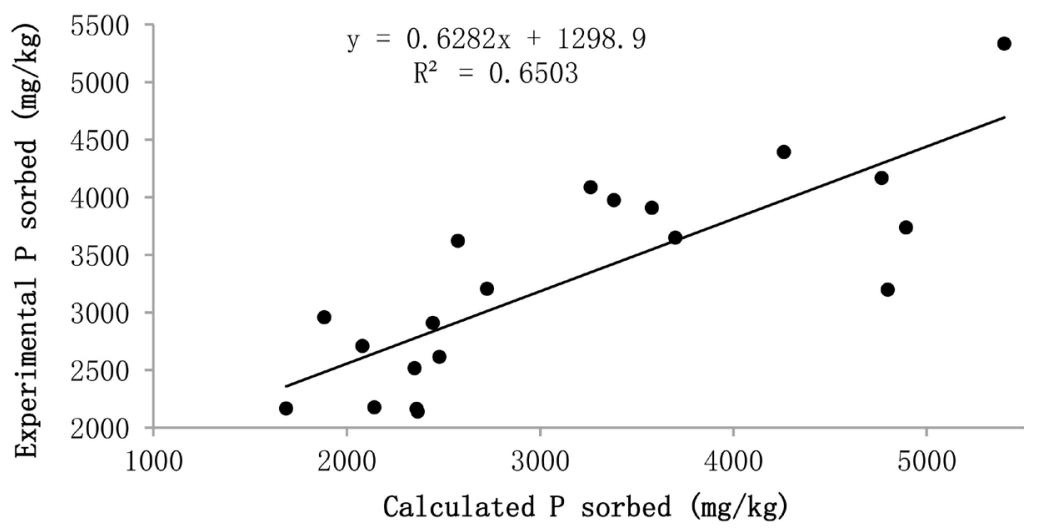

Figure 10. Correlation between experimentally determined $\mathrm{P}$ sorbed and estimated $\mathrm{P}$ sorbed using allophane and ferrihydrite contents (Equation (9)).

The higher coefficient of determination and correlation coefficient obtained for correlation between the experimental and theoretical P sorbed values (Equation (9)) as compared to the first equation (Equation (8)) indicates that the latter equation is more appropriate for estimation of $\mathrm{P}$ sorbed.

These regression equations can be used as a tool for quick assessment of $\mathrm{P}$ sorbed in soils of similar environments from data found in soil survey reports and soil laboratories. This will guide effective and efficient $\mathrm{P}$ fertilizer application and management.

\subsection{Oxalate and DCB Extractable $\mathrm{Al}, \mathrm{Fe}, \mathrm{Si}$, and Mn in Relation to P Sorption}

A second group of soil parameters $\left(\mathrm{Al}_{\mathrm{o}}, \mathrm{Fe}_{\mathrm{o}}, \mathrm{Si}_{\mathrm{o}}, \mathrm{Mn}_{\mathrm{o}}, \mathrm{Al}_{\mathrm{d}}, \mathrm{Fe}_{\mathrm{d}}, \mathrm{Si}_{\mathrm{d}}\right.$ and $\left.\mathrm{Mn}_{\mathrm{d}}\right)$ (Table 6) were also related to $\mathrm{P}$ sorption, to complement and or confirm some of the relationships earlier observed in this study.

From Table 7, it can be observed that $\mathrm{P}$ sorbed increases with Oxalate extractable $\mathrm{Al}, \mathrm{Fe}, \mathrm{Mn}$, and Si. This indicates that amorphous materials in these soils are the principal factors explaining $\mathrm{P}$ sorption. The highest correlation is observed for oxalate extractable aluminium indicating that active aluminium is the principal cause of high $\mathrm{P}$ sorption in these soils. The positive and significant correlation between this oxalate extractable aluminium and $\mathrm{pH}-\mathrm{NaF}(r=0.566$, $P<0.05)$ confirms that the latter component in these soils indicates the presence of amorphous materials, especially allophane, and hence could be conveniently used to estimate $\mathrm{P}$ adsorption. The positive and significant correlation between $\mathrm{OM}$ and oxalate extractable aluminium $(r=0.598, P<0.05)$ suggests the formation of organo-metallic complexes in these soils indicating that $\mathrm{OM}$ is a good indicator for $\mathrm{P}$ adsorption as there exists a co-correlation between $\mathrm{OM}$ and oxalate extractable aluminium through $\mathrm{pH}-\mathrm{NaF}$ data.

The fact that the amount of $\mathrm{P}$ sorbed correlates more with oxalate extractable $\mathrm{Al}, \mathrm{Fe}, \mathrm{Si}$, and $\mathrm{Mn}$ than $\mathrm{DCB}$ extractable forms, suggests that amorphous materials are the most important components responsible for $\mathrm{P}$ sorption. Studies by [41] have shown that these amorphous materials, especially iron, have high sur- 
face areas, which make them efficient sorbents for inorganic anions such as phosphates, biocides, etc. From the relationships between various forms of $\mathrm{Al}$, $\mathrm{Fe}, \mathrm{Si}$, and $\mathrm{Mn}$, parameters of sorption isotherms, and other selected physico-chemical characteristics (Table 7), the order of correlation of amorphous species is $\mathrm{Al}_{\mathrm{o}}>\mathrm{Si}_{\mathrm{o}}>\mathrm{Fe}_{\mathrm{o}}>\mathrm{Mn}_{\mathrm{o}}$. Aluminium and silicon are the dominant elements in allophanes.

In contrast to the first set of regression Equations, (8) and (9), where the accuracy of the dependent variable increases with the amorphous character of variables introduced, these second set of regression equations indicate that the

Table 6. Acid oxalate extractable $\mathrm{Al}, \mathrm{Fe}, \mathrm{Mn}, \mathrm{Si}\left(\mathrm{Al}_{\mathrm{o}}, \mathrm{Fe}_{\mathrm{o}}, \mathrm{Mn}_{\mathrm{o}}, \mathrm{Si}_{\mathrm{o}}\right)$ and DCB extractable $\mathrm{Al}$, $\mathrm{Fe}, \mathrm{Mn}, \mathrm{Si}\left(\mathrm{Al}_{\mathrm{d}}, \mathrm{Fe}_{\mathrm{d}}, \mathrm{Mn}_{\mathrm{d}}, \mathrm{Si}_{\mathrm{d}}\right)$ of selected soil horizons.

\begin{tabular}{|c|c|c|c|c|c|c|c|c|}
\hline \multirow{2}{*}{$\begin{array}{c}\text { Horizon } \\
\text { depth }(\mathrm{cm})\end{array}$} & $\mathrm{Al}_{\mathrm{o}}$ & $\mathrm{Fe}_{\mathrm{o}}$ & $\mathrm{Mn}_{\mathrm{o}}$ & $\mathrm{Si}_{\mathrm{o}}$ & $\mathrm{Al}_{\mathrm{d}}$ & $\mathrm{Fe}_{\mathrm{d}}$ & $\mathrm{Mn}_{\mathrm{d}}$ & $\mathrm{Si}_{\mathrm{d}}$ \\
\hline & \multicolumn{8}{|c|}{$\%$} \\
\hline \multicolumn{9}{|l|}{ Profile 1} \\
\hline$A(0-65)$ & 1.62 & 2.64 & 0.11 & 0.99 & 0.93 & 4.23 & 0.14 & 0.66 \\
\hline$A C(65-95)$ & 1.55 & 2.67 & 0.13 & 0.77 & 1.02 & 5.07 & 0.17 & 0.66 \\
\hline $\operatorname{Cr}(95-170)$ & 1.01 & 2.68 & 0.14 & 0.65 & 0.65 & 4.96 & 0.19 & 0.75 \\
\hline \multicolumn{9}{|l|}{ Profile 2} \\
\hline $\mathrm{A}(0-40)$ & 5.44 & 3.92 & 0.17 & 1.45 & 3.62 & 6.05 & 0.17 & 0.52 \\
\hline $\mathrm{AC}(40-50)$ & 7.65 & 5.47 & 0.16 & 2.69 & 3.91 & 7.89 & 0.16 & 0.58 \\
\hline \multicolumn{9}{|l|}{ Profile 3} \\
\hline Ap $(0-20)$ & 0.46 & 1.10 & 0.14 & 0.13 & 0.49 & 4.63 & 0.17 & 0.26 \\
\hline$A B(20-46)$ & 0.58 & 0.97 & 0.09 & 0.12 & 0.80 & 6.26 & 0.16 & 0.30 \\
\hline $\mathrm{Bw}_{2}(82-123)$ & 0.49 & 0.72 & 0.09 & 0.12 & 0.50 & 4.37 & 0.14 & 0.36 \\
\hline $\operatorname{Cr}(180-220)$ & 0.42 & 0.59 & 0.09 & 0.10 & 0.39 & 3.31 & 0.14 & 0.38 \\
\hline \multicolumn{9}{|l|}{ Profile 4} \\
\hline A $(4-27)$ & 5.42 & 3.39 & 0.10 & 2.72 & 2.26 & 5.99 & 0.12 & 0.74 \\
\hline $\mathrm{Bw}(27-50)$ & 6.50 & 3.50 & 0.08 & 3.39 & 2.78 & 7.04 & 0.12 & 0.94 \\
\hline $\mathrm{BC}(50-67)$ & 4.80 & 3.71 & 0.08 & 3.03 & 2.07 & 5.56 & 0.10 & 1.01 \\
\hline $2 C(86-100)$ & 3.34 & 3.85 & 0.07 & 2.69 & 1.40 & 4.74 & 0.08 & 1.01 \\
\hline $4 C(122-130)$ & 1.79 & 2.51 & 0.05 & 1.54 & 0.70 & 2.78 & 0.05 & 0.68 \\
\hline \multicolumn{9}{|l|}{ Profile 5} \\
\hline$A_{c}(8-47)$ & 4.47 & 4.08 & 0.15 & 2.66 & 2.81 & 10.66 & 0.21 & 1.14 \\
\hline $\mathrm{Cr}_{1}(47-132)$ & 5.19 & 4.06 & 0.16 & 2.71 & 4.16 & 11.78 & 0.23 & 1.11 \\
\hline $\mathrm{Cr}_{2}(132-220)$ & 8.07 & 5.42 & 0.17 & 5.43 & 3.23 & 11.29 & 0.23 & 1.28 \\
\hline \multicolumn{9}{|l|}{ Profile 6} \\
\hline $\mathrm{A}(0-45)$ & 4.88 & 4.58 & 0.12 & 3.32 & 1.43 & 7.00 & 0.14 & 0.99 \\
\hline $\operatorname{Cr}(45-60)$ & 1.90 & 5.19 & 0.12 & 2.06 & 0.68 & 6.38 & 0.13 & 1.10 \\
\hline $2 \mathrm{Cr}_{2}(130-180)$ & 0.94 & 4.55 & 0.12 & 1.59 & 0.42 & 5.38 & 0.13 & 1.12 \\
\hline
\end{tabular}


Table 7. Correlations between parameters of various sorption isotherms, selected physico-chemical properties, and various forms of $\mathrm{Al}, \mathrm{Fe}, \mathrm{Si}$, and $\mathrm{Mn}$.

\begin{tabular}{|c|c|c|c|c|c|c|c|c|}
\hline & $\% \mathrm{Al}_{\text {。 }}$ & $\% \mathrm{Fe}_{\mathrm{o}}$ & $\% \mathrm{Mn}_{\mathrm{o}}$ & $\% \mathrm{Si}_{\mathrm{o}}$ & $\% \mathrm{Al}_{\mathrm{d}}$ & $\% \mathrm{Fe}_{\mathrm{d}}$ & $\% \mathrm{Mn}_{\mathrm{d}}$ & $\% \mathrm{Si}_{\mathrm{d}}$ \\
\hline$c$ & $0.930^{* *}$ & $0.637^{\star *}$ & $0.608^{* *}$ & $0.768^{\star *}$ & $0.953^{* *}$ & $0.775^{\star *}$ & 0.464 & 0.409 \\
\hline$b(\mathrm{~kg} / \mathrm{L})$ & $0.922^{\star *}$ & $0.547^{\star}$ & $0.546^{*}$ & $0.734^{\star *}$ & $0.960^{* *}$ & $0.751^{\star *}$ & 0.466 & 0.361 \\
\hline$k(\mathrm{~L} / \mathrm{mg})$ & $0.710^{\star \star}$ & $0.499^{*}$ & $0.685^{\star \star}$ & $0.532^{*}$ & $0.721^{\star *}$ & $0.555^{\star}$ & $0.516^{\star}$ & 0.132 \\
\hline $1 / n(\mathrm{~L} / \mathrm{kg})$ & -0.414 & -0.426 & -0.427 & -0.313 & -0.456 & -0.398 & -0.243 & -0.063 \\
\hline$K_{d}$ & $0.794^{\star \star}$ & $0.535^{\star}$ & $0.641^{\star \star}$ & $0.602^{*}$ & $0.834^{* *}$ & $0.654^{\star *}$ & $0.501^{*}$ & 0.199 \\
\hline$n(\mathrm{~L} / \mathrm{kg})$ & 0.274 & 0.280 & 0.171 & 0.461 & 0.203 & 0.433 & 0.323 & $0.609^{\star *}$ \\
\hline$m\left(\mathrm{mg}^{2} / \mathrm{kg}^{2}\right)$ & $0.594^{*}$ & 0.301 & $0.550^{*}$ & 0.212 & $0.719^{* *}$ & 0.278 & 0.281 & -0.224 \\
\hline$a(\mathrm{mg} / \mathrm{kg})$ & $0.784^{\star *}$ & 0.383 & 0.368 & $0.485^{*}$ & $0.886^{* *}$ & $0.527^{*}$ & 0.203 & 0.137 \\
\hline$b(\mathrm{~mL} / \mathrm{g})$ & $0.628^{\star *}$ & 0.375 & 0.380 & $0.672^{* *}$ & $0.607^{* *}$ & $0.697^{\star *}$ & $0.516^{*}$ & 0.418 \\
\hline $\mathrm{pH}-\mathrm{H}_{2} \mathrm{O}$ & 0.250 & $0.764^{\star \star}$ & 0.250 & 0.478 & 0.038 & 0.153 & -0.100 & $0.687^{\star *}$ \\
\hline $\mathrm{pH}-\mathrm{KCl}$ & 0.145 & $0.701^{\star *}$ & 0.094 & 0.451 & -0.078 & 0.127 & -0.201 & $0.705^{\star *}$ \\
\hline $\mathrm{pH}-\mathrm{NaF}$ & $0.566^{*}$ & 0.269 & 0.339 & 0.196 & $0.603^{*}$ & 0.013 & -0.001 & -0.196 \\
\hline Sand (\%) & 0.242 & $0.552^{\star}$ & 0.454 & 0.454 & 0.276 & $0.559^{\star}$ & 0.386 & $0.696^{\star *}$ \\
\hline Silt (\%) & -0.177 & -0.374 & -0.350 & -0.251 & -0.267 & -0.375 & -0.234 & -0.385 \\
\hline Clay (\%) & -0.209 & $-0.529^{*}$ & -0.360 & $-0.535^{\star}$ & -0.125 & $-0.540^{\star}$ & -0.416 & $-0.817^{\star *}$ \\
\hline OM (\%) & $0.598^{*}$ & 0.374 & 0.260 & 0.367 & $0.598^{*}$ & 0.336 & 0.036 & 0.102 \\
\hline Alloph content (\%) & $0.933^{\star *}$ & $0.764^{\star *}$ & 0.338 & $0.986^{\star *}$ & $0.719^{* *}$ & $0.691^{\star *}$ & 0.192 & $0.678^{\star \star}$ \\
\hline Ferrih content (\%) & $0.698^{\star *}$ & $1.000^{* *}$ & $0.594^{*}$ & $0.784^{* *}$ & $0.564^{*}$ & $0.601^{*}$ & 0.200 & $0.764^{\star *}$ \\
\hline $\mathrm{Al}_{0}+1 / 2 \mathrm{Fe}_{\mathrm{o}}(\%)$ & $0.985^{\star \star}$ & $0.810^{\star *}$ & $0.507^{\star}$ & $0.901^{\star *}$ & $0.862^{\star *}$ & $0.698^{\star *}$ & 0.249 & $0.551^{*}$ \\
\hline
\end{tabular}

Alloph $=$ allophane, ferrih $=$ ferrihydrite, $\mathrm{Al} / \mathrm{Si}=\left(\mathrm{Al}_{\mathrm{o}}-\mathrm{Al}_{\mathrm{p}}\right) /\left(\mathrm{Si}_{\mathrm{o}}\right)$ molar ratio where ${ }_{\mathrm{o}}$ and $\mathrm{d}$ refer to oxalate and $\mathrm{DCB}$ extraction, respectively. ${ }^{* *} \mathrm{Correlation}$ is significant at the 0.01 level (2-tailed), $\mathrm{P} \leq 0.01 ;{ }^{*}$ Correlation is significant at the 0.05 level (2-tailed), $P \leq 0.05$.

simple linear Equations (10) and (11) would be more accurate in P sorption assessment.

$$
\begin{aligned}
& \text { P sorbed }=392\left(\mathrm{Al}_{\mathrm{o}}\right)+1942, \quad R^{2}=0.864 \\
& \text { P sorbed }=799\left(\mathrm{Al}_{\mathrm{d}}\right)+1860, \quad R^{2}=0.908 \\
& \text { P sorbed }=458\left(\mathrm{Al}_{\mathrm{o}}\right)-135\left(\mathrm{Si}_{\mathrm{o}}\right)+1979, \quad R^{2}=0.854 \\
& \text { P sorbed }=455\left(\mathrm{Al}_{\mathrm{o}}\right)-163\left(\mathrm{Si}_{\mathrm{o}}\right)+36\left(\mathrm{Fe}_{\mathrm{o}}\right)+1915, \quad R^{2}=0.843 \\
& \mathrm{P} \text { sorbed }=713\left(\mathrm{Al}_{\mathrm{d}}\right)+61\left(\mathrm{Si}_{\mathrm{d}}\right)+1612, \quad R^{2}=0.905
\end{aligned}
$$

The developed regression Equations (10)-(14) indicate that $\mathrm{P}$ sorption is more associated with DCB extractable species compared to the oxalate extractable species. DCB extractable species includes crystalline, amorphous and organic forms. The difference between DCB and oxalate extractable species generally gives an idea of the crystalline forms of the corresponding species. In these soils, the concentrations of DCB extractable $\mathrm{Al}$ and $\mathrm{Si}$ (which are the dominant compo- 
nents of allophane) are lower than the oxalate extractable forms (a common observation in tephra soils) [42], indicating that DCB extractable $\mathrm{Al}$ and $\mathrm{Si}$ is dominated by amorphous forms and so the high correlation coefficients in Equations (10) and (11) are evident.

As observed above, the sorption parameters of the various sorption isotherms correlate with the various forms of DCB and acid oxalate extractable $\mathrm{Al}, \mathrm{Si}, \mathrm{Fe}$, and $\mathrm{Mn}$. The Langmuir parameters correlate with $\mathrm{Al}_{\mathrm{o}}, \mathrm{Fe}_{\mathrm{o}}, \mathrm{Mn}_{\mathrm{o}}, \mathrm{Si}_{\mathrm{o}}, \mathrm{Al}_{\mathrm{d}}$ and $\mathrm{Fe}_{\mathrm{d}}$. The $k_{d}$ parameter of the Freundlich equation shows the highest degree of association as it correlates with all parameters except $\mathrm{Si}_{\mathrm{d}}$. The fact that $\mathrm{P}$ sorbed correlates with amorphous forms of $\mathrm{Al}, \mathrm{Fe}, \mathrm{Si}$, and $\mathrm{Mn}$ compared to the free forms of the latter elements suggests that in these soils amorphous materials are the dominant species responsible for $\mathrm{P}$ sorption.

\section{Conclusions}

P sorption studies showed that $\mathrm{P}$ sorption capacity of the six tephra soils varied from 2080 to $5402 \mathrm{mg} / \mathrm{kg}$. However, these values do not constitute the sorption maxima for these soils as higher $\mathrm{P}$ equilibrium concentrations were not introduced. The soil parameters that relate to $\mathrm{P}$ sorption in these soils are $\mathrm{OM}, \mathrm{pH}-\mathrm{NaF}$, allophane content, ferrihydrite content, $\% \mathrm{Al}_{\mathrm{o}}, \% \mathrm{Fe}_{\mathrm{o}}, \% \mathrm{Mn}_{\mathrm{o}}, \% \mathrm{Si}_{\mathrm{o}}, \% \mathrm{Al}_{\mathrm{d}}, \% \mathrm{Fe}_{\mathrm{d}}$, but also $\mathrm{Al}_{0}+1 / 2 \mathrm{Fe}_{o}$. Presence of amorphous materials can be assessed through $\mathrm{pH}-\mathrm{NaF}$ tests in these tephra soils as confirmed through the high and significant correlation established among them and constitutes the dominant species influencing P sorption.

All four equilibrium based models used for the description of $\mathrm{P}$ sorption in these soils fit the data satisfactorily. However, based on the parameters of the models, the Freundlich and Langmuir models best describe P sorption. Multiple linear regression equations can be used to estimate $\mathrm{P}$ sorption capacity of similar soils if data is available.

The results of this study are in agreement with those of [43] and [32] who reported that $\mathrm{pH}-\mathrm{NaF}$ can be used in Andosols and sesquioxidic soils to estimate $\mathrm{P}$ sorption. Because soils in this study belong to two main Reference Soil Groups (Andosols and Cambisols with few andic properties), it can be generalised that for variable charged soils, or soils developed from volcanic parent materials, $\mathrm{pH}-\mathrm{NaF}$ can be used as a reliable parameter for estimating $\mathrm{P}$ sorption.

$\mathrm{P}$ sorption studies to be effective require much time, high concentration, are costly, and often not affordable to most users. Assessment of $\mathrm{P}$ sorption and $\mathrm{P}$ requirements from parameters found in soil survey reports and other sources would minimize $P$ fertility management costs. The confirmed relationship that exists between $\mathrm{pH}-\mathrm{NaF}$ and amorphous components as determined through DCB and oxalate extractable $\mathrm{Al}, \mathrm{Fe}$ and $\mathrm{Si}$ and their relationship to $\mathrm{P}$ sorption provides a possible pathway for estimation of $\mathrm{P}$ sorption directly using $\mathrm{pH}-\mathrm{NaF}$ which is much less expensive than long established procedures. This is very important for the Andosols of the humid tropics where a paucity of such studies exist. 
The continued high crop performance observed in some tephra soils having low $\mathrm{pHs}(\mathrm{pH} \leq 5.5)$, where exchangeable $\mathrm{Al}$ would be present and fix $\mathrm{P}$, a major plant element had been puzzling. The mechanism for $\mathrm{Al}$ adsorption on the allophane-OM complex is inherent in these systems, thus liberating $\mathrm{P}$ for plant use required elucidation. The mechanism for Al-adsorption to $\mathrm{OM}$ on the allophane-OM complex outlined in this study explains in part the on-going process in these tephra soils.

\section{Conflicts of Interest}

The authors declare no conflicts of interest regarding the publication of this paper.

\section{References}

[1] Sparks, D.L. (2003) Environmental Soil Chemistry. 2nd Edition, Academic Press, Oxford. https://doi.org/10.1016/B978-012656446-4/50001-3

[2] Pansu, M. and Gautheyrou, J. (2006) Handbook of Soil Analysis. Mineralogical, Organic and Inorganic Methods. Springer-Verlag, Berlin, Heidelberg. https://doi.org/10.1007/978-3-540-31211-6

[3] Xu, R.K., Qafoku, N.P., Van Ranst, E., Li, J.Y. and Jiang, J. (2016) Adsorption Properties of Subtropical and Tropical Variable Charge Soils: Implications from Climate Change and Biochar Amendment. In: Sparks, D., Ed., Advances in Agronomy, Vol. 135, Academic Press, Chennai, 1-58. https://doi.org/10.1016/bs.agron.2015.09.001

[4] Shoji, S., Nanzyo, M. and Dahlgren, R.A. (1993) Volcanic Ash Soils: Genesis, Properties and Utilization. Developments in Soil Science Vol. 21. Elsevier, New York.

[5] Van Ranst, E., Hof, J., Kips, P.A., Awah, E.T. and Zambo, J. (1989) Volcanic Soils of the Lower South Eastern and Eastern Slopes of Mount Cameroon (West Africa). Research Project UCD. Technical Report. FAO/UNDP Project CMR/83/004.

[6] Cabello, M.J., Boem, F.H.G., Quintero, C.E. and Rubio, G. (2016) Soil Characteristics Involved in Phosphorus Sorption in Mollisols. Soil Science Society of America Journal, 80, 1585-1590. https://doi.org/10.2136/sssaj2016.07.0235n

[7] Fink, J.R., Inda, A.V., Tiecher, T. and Barrón, V. (2016) Iron Oxides and Organic Matter on Soil Phosphorus Availability. Ciência e Agrotecnologia, 40, 369-379. https://doi.org/10.1590/1413-70542016404023016

[8] Limousin, G., Gaudet, J.P., Charlet, L., Szenknect, S., Barthès, V. and Krimissa, M. (2007) Sorption Isotherms: A Review on Physical Bases, Modelling and Measurement. Applied Geochemistry, 22, 249-275. https://doi.org/10.1016/j.apgeochem.2006.09.010

[9] Langmuir, I. (1918) The Adsorption of Gases on Plane Surfaces of Glass, Mica and Platinum. Journal of American Chemical Society, 40, 1361-1382. https://doi.org/10.1021/ja02242a004

[10] Freundlich, H. (1926) Colloid and Capillary Chemistry. Methuen and Co. Ltd., London.

[11] Temkin, M.I. and Pyzhev, V. (1940) Recent Modifications to the Langmuir Isotherms. Acta Physico-Chimica Sinica, 12, 217-222.

[12] Pagel, H. and Van Huay, H. (1976) Wichtige Parameter der Phosphat-sorptionskur-ven einiger Boden der Tropen und Subtropen und ihre zeit-liche Veranderung durch 
P-Dungung. Arch. Acker-u-Pflanzenbau u Bodenkd, 20, 765-778.

[13] Gèze, B. (1943) Géographie physique et géologie du Cameroun occidental. Vol. 1. Édi-tions du Muséum, Paris.

[14] Nkouathio, D.G., Kagou, D.A., Bardintzeff, J.M., Wandji, P., Bellon, H. and Pouclet, A. (2008) Evolution of Volcanism in Graben and Horst Structures along the Cenozoic Cameroon Line (Africa): Implications for Tectonic Evolution and Mantle Source Composition. Mineralogy and Petrology, 94, 287-303. https://doi.org/10.1007/s00710-008-0018-1

[15] Enang, R.K., Yerima, B.P.K., Kome, G.K. and Van Ranst, E. (2017) Effects of Forest Clearance and Cultivation on Bulk Density Variations and Relationships with Texture and Organic Matter in Tephra Soils of Mount Kupe (Cameroon). Communications in Soil Science and Plant Analysis, 48, 2231-2245. https://doi.org/10.1080/00103624.2017.1407785

[16] Pouclet, A., Kagou, D.A., Bardintzeff, J.M., Wandji, P., Chakam, T.P., Nkouathio, D.G., Bellon, H. and Ruffet, G. (2014) The Mount Manengouba, a Complex Volcano of the Cameroon Line: Volcanic History, Petrological and Geochemical Features. Journal of African Earth Sciences, 97, 297-321. https://doi.org/10.1016/j.jafrearsci.2014.04.023

[17] FAO (2006) Guidelines for Soil Description. 4th Edition, FAO, Rome.

[18] Enang, R.K., Yerima, B.P.K., Kome, G.K. and Van Ranst, E. (2018) Assessing the Effectiveness of the Walkley-Black Method for Soil Organic Carbon Determination in Tephra Soils of Cameroon. Communications in Soil Science and Plant Analysis, 49, 2379-2386. https://doi.org/10.1080/00103624.2018.1510948

[19] Soil Survey Staff (1996) Soil Survey Laboratory Methods Manual. Procedures for Collecting Soil Samples and Methods of Analysis for Soil Survey, Soil Survey Investigation Report No. 42, Version 3.0. USDA, Washington DC.

[20] Parfitt, R.L. and Wilson, A.D. (1985) Estimation of Allophane and Halloysite in Three Sequences of Volcanic Soils. In: Fernandez-Caldos, E. and Yaalon, D.H., Eds., Volcanic Soils, Weathering and Landscape Relationships of Soils on Tephra and Basalt (Catena Supplement Vol. 7), ISSS-AISS-IBG, Cremlingen, 1-8.

[21] Childs, C.W. (1985) Towards Understanding Soil Mineralogy: II. Notes on Ferrihydrite. NZ Soil Bureau Laboratory Report CM7, Lower Hutt.

[22] Craze, B. (1995) Phosphorus Sorption. Soil Survey Standard Test Method. DSNR.

[23] OriginLab (2000) Origin 6.0: Scientific Data Analysis and Graphing Software Origin Lab Corporation. Northampton.

[24] Microsoft Corporation (2006) Microsoft Office Excel for Windows Version 2007.

[25] SPSS Inc. (2008) SPSS Statistics for Windows, Version 17.0. SPSS Inc., Chicago.

[26] Evangelou, V.P. (1998) Environmental Soil and Water Chemistry: Principles and Applications. John Wiley \& Sons, New York.

[27] Brenner, J., Porter, W., Phillips, J.R., Childs, J., Yang, X. and Mayes, M.A. (2019) Phosphorus Sorption on Tropical Soils with Relevance to Earth System Model Needs. Soil Research, 57, 17-27. https://doi.org/10.1071/SR18197

[28] IUSS Working Group WRB (2015) World Reference Base for Soil Resources 2014, Update 2015: International Soil Classification System for Naming Soils and Creating Legends for Soil Maps. World Soil Resources Report No. 106. FAO, Rome.

[29] Van Breemen, N. and Buurman, P. (2002) Soil Formation. Kluwer Academic Publishers, Dordrecht. https://doi.org/10.1007/0-306-48163-4 
[30] Latrille, C., Denaix, L. and Lamy, I. (2003) Interaction of Copper and Zinc with Allophane and Organic Matter in the B Horizon of an Andosol. European Journal of Soil Science, 54, 357-364. https://doi.org/10.1046/j.1365-2389.2003.00530.x

[31] Schulin, R., Johnson, A. and Frossard, E. (2010) Trace Element-Deficient Soils. In: Hooda, P.S., Ed., Trace Elements in Soils, Blackwell Publishing, Hoboken, 175-194. https://doi.org/10.1002/9781444319477.ch9

[32] Singh, B. and Gilkes, R.J. (1991) Phosphorus Sorption in Relation to Soil Properties for the Major Soil Types of South-Western Australia. Australian Journal of Soil Research, 29, 603-618. https://doi.org/10.1071/SR9910603

[33] Gilkes, R.J. and Hughes, J.C. (1994) Sodium-Fluoride pH of South-Western Australian Soils as an Indicator of P Sorption. Australian Journal of Soil Research, 32, 755-766. https://doi.org/10.1071/SR9940755

[34] Borggaard, O.K., Jørgensen, S.S., Møberg, J.P. and Raben-Lange, B. (1990) Influence of Organic Matter on Phosphate Adsorption by Aluminium and Iron Oxides in Sandy Soils. Journal of Soil Science, 41, 443-449. https://doi.org/10.1111/j.1365-2389.1990.tb00078.x

[35] Debicka, M., Kocowicz, A., Weber, J. and Jamroz, E. (2015) Organic Matter Effects on Phosphorous Sorption in Sandy Soils. Archives of Agronomy and Soil Science, 62, 840-855. https://doi.org/10.1080/03650340.2015.1083981

[36] Harsh, J. (2005) Amorphous Materials. In: Hillel, D., Hatfield, J.L., Powlson, D.S., Ro-senzweig, C., Scow, K.M., Singer, M.J. and Sparks, D.L., Eds., Encyclopedia of Soils in the Environment, Elsevier, Amsterdam, 64-71. https://doi.org/10.1016/B0-12-348530-4/00207-1

[37] Zhao, X., Zhong, X. and Li. G. (2006) The Evaluation of Phosphorus Leaching Risk of 23 Chinese Soils II. The Relationships between Soils Properties, P Adsorption Characteristics and the Leaching Criterion. Acta Ecologica Sinica, 26, 3011.

[38] Parfitt, R.L., Hume, L.J. and Sparling, G.P. (1989) Loss of Availability of Phosphate in Some New Zealand Soils. Journal of Soil Science, 40, 371-382. https://doi.org/10.1111/j.1365-2389.1989.tb01281.x

[39] Wada, S.I. and Wada, K. (1977) Density and Structure of Allophane. Clay Minerals, 12, 289-298. https://doi.org/10.1180/claymin.1977.012.4.02

[40] Van Ranst, E., Utami, S.R., Vanderdeelen, J. and Shamshuddin, J. (2004) Surface Reactivity of Andosols on Volcanic Ash along the Sunda Arc Crossing Java Island, Indonesia. Geoderma, 123, 193-203. https://doi.org/10.1016/j.geoderma.2004.02.005

[41] Schwertmann, U. and Taylor, R.M. (1989) Iron Oxides. In: Dixon, J.B. and Weed S.B., Eds., Minerals in Soil Environments, 2nd Edition, Soil Science Society of America, Inc., Madison, 379-438.

[42] Colombo, C., Sellitto, M.V., Palumbo, G., Terribile, F. and Stoops, G. (2007) Characteristics and Genesis of Volcanic Soils from South Central Italy: Mt. Gauro (Phlegraean Fields, Campania) and Vico Lake (Latium). In: Arnalds, O., Bartoli, F., Buurman, P., Óskarsson, H., Stoops, G. and García-Rodeja, E., Eds., Soils of Volcanic Regions in Europe, Springer-Verlag, Heidelberg, Berlin, 197-229.

https://doi.org/10.1007/978-3-540-48711-1 18

[43] Alvarado, A. and Buol, S.W. (1985) Field Estimation of Phosphate Retention by Andepts. Soil Science Society of America Journal, 49, 911-914.

https://doi.org/10.2136/sssaj1985.03615995004900040024x 